\title{
Paleozoic and Mesozoic Deformations in the Central Sierra Nevada, California
}

GEOLOGICAL SURVEY PROFESSIONAL PAPER 1145

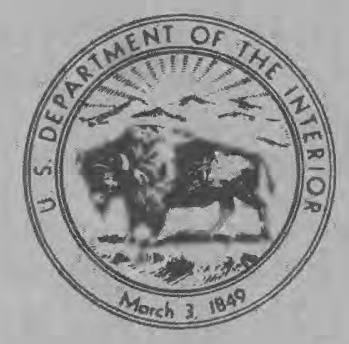




\section{Paleozoic and Mesozoic Deformations in the Central Sierra Nevada, California}

By WARREN J. NOKLEBERG and RONALD W. KISTLER

GEOLOGICAL SURVEY PROFESSIONAL PA PER 1145

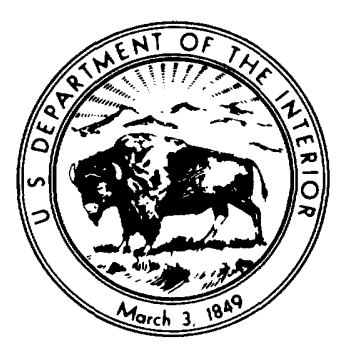

\begin{tabular}{llllll}
\hline UNITED & STATES & GOVERNMENT & PRINTING OFFICE, & WASHINGTON & : 1980
\end{tabular} 


\title{
UNITED STATES DEPARTMENT OF THE INTERIOR
}

CECIL D. ANDRUS, Secretary

\author{
GEOLOGICAL SURVEY
}

H. William Menard, Director

\section{Library of Congress Cataloging in Publication Data}

Nokleberg, Warren $\mathrm{J}$

Paleozoic and Mesozoic deformations in the central Sierra Nevada, California.

(Geological Survey professional paper ; 1145) Bibliography: p. 22-24.

Supt. of Docs. no.: I 19.16:1145

1. Rock deformation--Sierra Nevada Mountains. 2. Geology--Sierra Nevada Mountains. I. Kistler, Ronald Wayne, 193I- joint author. II. Title. III. Series: United States. Geological Survey. Professional paper ; 1145.

QE604.N64 551.8:09794:4 80-607011

For sale by the Superintendent of Documents, U.S. Government Printing Office Washington, D.C. 20402

Stock number 024-001-03293-7 


\section{CONTENTS}

\begin{tabular}{|c|c|}
\hline $\mathrm{Pag}$ & Page \\
\hline troduction & Nevadan orogeny in the western metamorphic belt \\
\hline roblems of Sierra Nevada deformational history & Orientation and style of structures \\
\hline leozoic deformations & Timing of deformation and regional correlations _._. 14 \\
\hline structures & high-country roof pendants \\
\hline Style of deformation & Orientation and style of structures \\
\hline Timing of deformation and regional correlations & Timing of deformation and regional correlations \\
\hline Mesozoic deformations & Timing of deformation and regional structures \\
\hline Areal extent & Continuing problems \\
\hline Triassic regional deformation of high-country roof pendants & Episodic or continuous deformation? \\
\hline le of structures & Role of granitic intrusions \\
\hline ional correlations _..... & Conjugate folds \\
\hline eformation .......... & Conclusions - \\
\hline
\end{tabular}

\section{ILLUSTRATIONS}

Figure 1. Generalized geologic map of the central Sierra Nevada

. Structural diagrams for areas deformed during the Devonian or Misian period along north-south trends

3. Structural diagrams for three high-Sierra Nevada roof pendants

4. Structural diagrams for parts of the Calaveras Formation

5. Structural diagrams for areas of the western metamorphic belt

6. Structural diagram of poles to bedding - .

7. Structural diagrams for high-country roof pendants deformed probably during Jurassic orogenies

8. Structural diagrams for high-country roof pendants and areas of the western metamorphic belt

\section{TABLES}

1. Regional deformations recorded in roof pendants and wallrocks of the central Sierra $\mathrm{Nevada}$
2. Data for figure 2
3. Data for figure 3
4. Data for figure 4
6. Data for figure 5
7. $\quad$ Data sources for figure 6
8. $\quad$ Data for figure 7





\title{
PALEOZOIC AND MESOZOIC DEFORMATIONS IN THE CENTRAL SIERRA NEVADA, CALIFORNIA
}

\author{
By WarRen J. NoKLeberg and Ronald W. Kistler
}

\section{ABSTRACT}

Analysis of structural and stratigraphic data indicates that several periods of regional deformation, consisting of combined folding, faulting, cataclasis, and regional metamorphism, occurred throughout the central Sierra Nevada during Paleozoic and Mesozoic time. The oldest regional deformation occurred alono northward trends during the Devonian and Mississippian periods in most roof pendants containing lower Paleozoic metasedimentary rocks at the center and along the crest of the range. This deformation is expressed in some roof pendants by an angular unconformity separating older thrice-deformed from younger twice-deformed Paleozoic metasedimentary rocks.

The first Mesozoic deformation, which consisted of uplift and erosion and was accompanied by the onset of Andean-type volcanism during the Permian and Triassic, is expressed by an angular unconformity in several roof pendants from the Saddlebag Lake to the Mount Morrison areas. This unconformity is defined by Permian and Triassic andesitic to rhyolitic metavolcanic rocks unconformably overlying more intensely deformed Pennsylvanian, Permian(?), and older metasedimentary rocks. A later regional deformation occurred during the Triassic along N. $20^{\circ}-30^{\circ} \mathrm{W}$. trends in Permian and Triassic metavolcanic rocks of the Saddlebag Lake and Mount Dana roof pendants, in upper Paleozoic rocks of the Pine Creek roof pendant, and in the Calaveras Formation of the western metamorphic belt; the roof pendants are crosscut by Upper Triassic granitic rocks of the Lee Vining intrusive epoch. A still later period of Early and Middle Jurassic regional deformation occurred along N. $30^{\circ}-60^{\circ} \mathrm{E}$. trends in upper Paleozoic rocks of the Calaveras Formation of the western metamorphic belt. A further period of deformation was the Late Jurassic Nevadan orogeny, which occurred along N. $20^{\circ}-40^{\circ} \mathrm{W}$. trends in Upper Jurassic rocks of the western metamorphic belt that are crosscut by Upper Jurassic granitic rocks of the Yosemite intrusive epoch. Structures of similar age occur in intensely deformed oceanic-lithospheric and syntectonic plutonic rocks of the lower Kings River area, in Jurassic metavolcanic rocks of the Ritter Range roof pendant, and in Triassic metasedimentary rocks of the Mineral King roof pendant. The final Mesozoic deformation occurred along $\mathrm{N}$. $50^{\circ}-80^{\circ} \mathrm{W}$. trends in both high-country roof pendants and the lower Kings River area; structures of this generation are crosscut by relatively undeformed Upper Cretaceous granitic rocks of the Cathedral Range intrusive epoch.

\section{INTRODUCTION}

Considerable controversy persists over the deformational history of intruded wallrocks of the Sierra Nevada in California. Three major interpretations are current: (1) a complex faulted synclinorium with main structural grain resulting from the Late Jurassic Nevadan orogeny (Bateman and others, 1963; Bateman and Clark, 1974); (2) accretion of Mesozoic country rocks onto the west side of the range against an Andean-type volcanic arc (Hamilton, 1969, 1978; Schweickert and Cowan, 1975; Davis and others, 1978; Schweickert, 1978); and (3) an anticlinorium that formed as a result of multiple deformations (Kistler and others, 1971). In this report we test these interpretations by examining geologic structures in the different roof pendants and in areas of the western metamorphic belt that have already been studied in detail. From rock ages and the style and orientation of regional structures, we envision successive generations of deformations, infer their causes, and bracket their durations.

Previous reports that discussed the tectonics of the range include studies of the Alpine County area (Parker, 1961), the Mono Craters quadrangle (Kistler, 1966a, b), the Dinkey Creek roof pendant (Kistler and Bateman, 1966), and the Mount Morrison roof pendant (Russell and Nokleberg, 1974, 1977). Valuable new information on the structure, stratigraphy, and rock ages of roof pendants and areas of the western metamorphic belt is available from recent detailed studies of the Strawberry mine roof pendant (Nokleberg, 1970a, b), the Saddlebag Lake roof pendant (Brook, 1972, 1974, 1977), the Ritter Range roof pendant (Kistler, 1966a, b; Fiske and Tobisch, 1978), the Boyden Cave roof pendant (Girty, 1977a, b), the lower Kings River area (Saleeby, 1974, 1975, 1976, 1978; Nokleberg, 1975; Saleeby and others, 1978), the Merced River area (W. J. Nokleberg, unpub. data, 1978), the Oakhurst roof pendant (Russell and Cebull, 1977), and the western metamorphic belt (Baird, 1962; Best, 1963; Wetzel and Nokleberg, 1976; Schweickert and others, 1977; Schweickert, 1978). We have also made use of structural data from the geologic maps by Taliaferro and Solari (1948), Clark (1954, 1964, 1970), Eric, Stromquist, and Swinney (1955), Mannion (1960), Christensen (1963), Bateman (1965), Huber and Rinehart (1965), and Duffield and Sharp (1975). 


\section{PROBLEMS OF SIERRA NEVADA DEFORMATIONAL HISTORY}

Besides discussing the controversy over the general structure of the country rocks, in this report we present critical evidence on the following questions regarding the deformational history of the area and the age groups of regional rocks: (1) Have multiple regional deformations, widely spaced in time, generated in successively older sequences of rocks progressively more superposed structures (Kistler, 1966a; Kistler and Bateman, 1966; Nokleberg, 1970a, b; Brook, 1972, 1974, 1977; Nokleberg, 1975; Wetzel and Nokleberg, 1976; Russell and Nokleberg, 1977)? (2) Does the Mount Morrison roof pendant comprise a thick homoclinal sequence on the east limb of a synclinorium (Rinehart and Ross, 1964), or a series of isoclinally folded units (Russell and Nokleberg, 1977)? (3) Are the Antler, Sonoman, and other orogenies of the Great Basin recorded in country rocks of the Sierra Nevada (Speed and Kistler, 1977)? (4) Were some multiple deformations merely conjugate folds formed during a single event (Tobisch and Fiske, 1976)? (5) Did a single principal Mesozoic deformation, the Late Jurassic Nevadan orogeny (Bateman and others, 1963; Bateman and Clark, 1974), occur, or several superposed deformations with subparallel northwestward trends (Russell and Nokleberg, 1977), or simply one continuing deformation over a long period (Hamilton, 1978)? (6) Do major angular unconformities exist that separate older more highly deformed from younger less deformed rocks (Morgan and Rankin, 1972; Brook and others, 1974)?

\section{PALEOZOIC DEFORMATIONS}

Significant evidence exists for two Paleozoic regional deformations in roof pendants along the center and crest of the Sierra Nevada. A Devonian or Mississippian regional deformation, possibly the Antler orogeny, occurs in Ordovician and Silurian(?) metasedimentary rocks of the Mount Morrison roof pendant (Russell and Nokleberg, 1977), and similar structures are present in lower Paleozoic rocks of the Log Cabin mine, Bishop Creek, and Dinkey Creek roof pendants over a distance of $112 \mathrm{~km}$ (fig. 1). A Late Permian regional deformation consisting of uplift, erosion, and onset of Andean-type volcanism is expressed by an angular unconformity exposed from the Saddlebag Lake roof pendant in the north to the Mount Morrison roof pendant in the south, over a distance of about $70 \mathrm{~km}$ (fig. 1). This unconformity marks a major change in sedimentation from Paleozoic miogeosynclinal sedimentary rocks named the Lewis sequence (Kistler, 1966a) to lower and middle Mesozoic metavol- canic rocks named the Koip and Dana sequences, respectively (Kistler, 1966a). The Paleozoic as well as Mesozoic deformations that we define for the central Sierra Nevada are listed below (table 1) by age of deformation, rock age, and locality, along with the data sources. Our table is based on the ideas of Kistler (1966a), Kistler and Bateman (1966), and Russell and Nokleberg (1977), who suggested that the similarities in structural style and orientation of distant roof pendants and of areas of the western metamorphic belt reflect regional deformations that occurred over widely separated intervals.

\section{DEVONIAN OR MISSISSIPPIAN REGIONAL DEFORMATION}

\section{ORIENTATION OF STRUCTURES}

The accompanying diagrams (figs. 2-8) show lowerhemisphere equal-area projections of structural data on regional deformations in the Sierra Nevada; data sources are listed either in the figures or in their corresponding tables (tables $2-8$ ). The diagrams showing structures formed during the Devonian and Mississippian regional deformation also give the average attitudes of axial planes and schistosities (figs. $2 A$, $2 \mathrm{D}, 2 \mathrm{H}$ ). We take the term "schistosity" as synonymous with "axial-plane cleavage." These diagrams of axial planes and schistosities are useful for the correlation of structures between isolated areas because the axial surfaces of folds tend to be initially planar in spite of preexisting variations in the fold orientation of bedding or foliation. Later deformation of an earlier generation of folds tended to create a simpler structure in the axial planes than in other elements, such as the fold axes or bedding (Weiss, 1959). The Devonian or Mississippian deformational structures are the oldest known in the central Sierra Nevada and consequently were most likely be to reoriented during later regional deformations. In each area studied, however, the dominant orientations of axial planes and schistosities are remarkably uniform and show average strikes of from N. $10^{\circ} \mathrm{W}$. to north and nearly vertical dips. In the Dinkey Creek roof pendant (fig. $2 \mathrm{H}$ ) axial planes have been rotated along a great circle that defines a northwest-plunging fold axis; we attribute this warping and rotation to refolding during a later Mesozoic deformation.

The fold axes and parallel lineations resulting from the Devonian or Mississippian regional deformation (figs. $2 B, 2 E, 2 I$ ) show a less preferred orientation than the corresponding axial planes because the orientations of fold axes are controlled in part by folding of the preexisting-surface orientation and may vary considerably, especially where earlier folds exist (Weiss, 1959). The maxima of fold axes, which plunge gently 


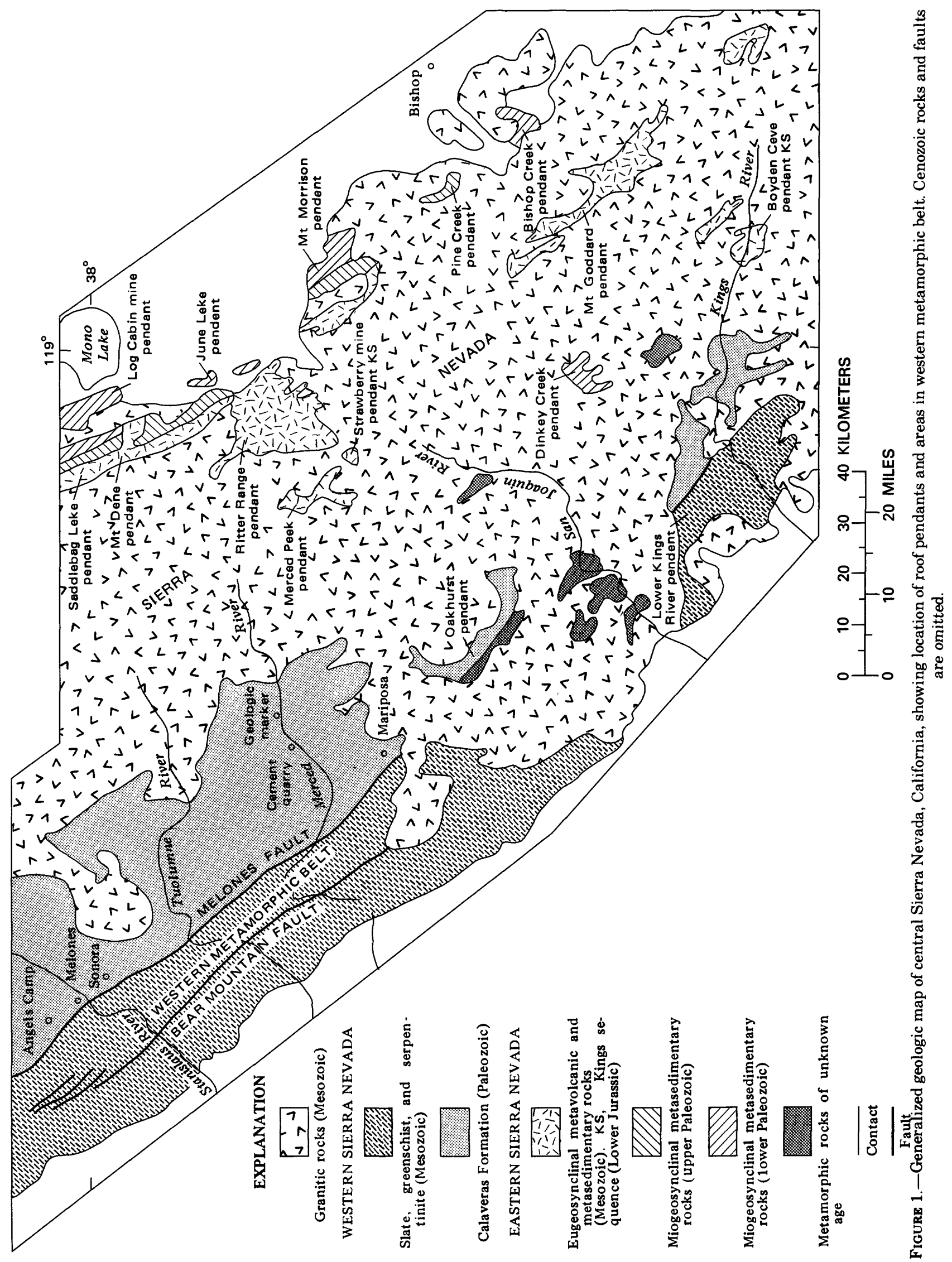


TABLE 1.-Regional deformations recorded in roof pendants and wallrocks of the central Sierra Nevada

\begin{tabular}{|c|c|c|c|c|c|}
\hline \multicolumn{6}{|c|}{ Age of deformation, including average strike of fold axial planes, rock types, and age of younger rocks for each area } \\
\hline Area & $\begin{array}{c}\text { Devonian or Mississippian } \\
\text { deformation }\end{array}$ & Triassic deformation & $\begin{array}{c}\text { Early and Middle } \\
\text { Jurassic deformation }\end{array}$ & $\begin{array}{l}\text { Late Jurassic Nevadan } \\
\text { orogeny }\end{array}$ & Cretaceous deformation \\
\hline $\begin{array}{l}\text { Bishop Creek } \\
\text { (Bateman, 1965) }\end{array}$ & $\begin{array}{l}\mathrm{N} \text {. } \\
\text { Metasedimentary rocks, } \\
\text { Ordovician (?) and } \\
\text { Silurian (?) }\end{array}$ & -.....- & bordered by & Upper Triassic granite & $-\ldots-\ldots$ \\
\hline $\begin{array}{l}\text { Log Cabin mine } \\
\quad \text { (Kistler, 1966) }\end{array}$ & $\begin{array}{l}\mathrm{N} . \\
\text { Metasedimentary rocks, } \\
\text { Ordovician (?) and } \\
\text { Silurian (?) }\end{array}$ & $\ldots \ldots-\ldots$ & bordered by & Upper Triassic granite & $-\cdots-\ldots$ \\
\hline $\begin{array}{l}\text { Dinkey Creek } \\
\text { (Kistler and Bateman, } \\
\text { 1966) }\end{array}$ & $\begin{array}{l}\text { N. } 5^{\circ} \mathrm{E} \text {. } \\
\text { Metasedimentary rocks, } \\
\text { Paleozoic (?) }\end{array}$ & - - & -......- & $\begin{array}{l}\text { N. } 25^{\circ} \mathrm{W} . \\
\text { Same rocks }\end{array}$ & $\begin{array}{l}\text { N. } 60^{\circ} \mathrm{W} . \\
\text { Same rocks }\end{array}$ \\
\hline $\begin{array}{l}\text { Mount Morrison } \\
\text { (Russell and Nokleberg, } \\
\text { 1974, 1977) }\end{array}$ & $\begin{array}{l}\text { N. } 8^{\circ} \mathrm{W} \text {. } \\
\text { Metasedimentary rocks, } \\
\text { Ordovician and Silurian (?) }\end{array}$ & Angular unconformity & (-... & $\begin{array}{l}\mathrm{N} .30^{\circ} \mathrm{W} \text {. } \\
\text { Metasedimentary rocks } \\
\text { Mesozoic metavolcanic } \\
\text { rocks }\end{array}$ & $\begin{array}{l}\text { N. } 60^{\circ} \mathrm{W} \text {. } \\
\text { Same rocks }\end{array}$ \\
\hline $\begin{array}{l}\text { Saddlebag Lake } \\
\text { (Brook, 1972, 1974, } \\
\text { 1977) }\end{array}$ & $\begin{array}{l}\text { N. } 8^{\circ} \mathrm{W} \text {. } \\
\text { Metasedimentary rocks, } \\
\text { Ordovician (?) and } \\
\text { Silurian (?) }\end{array}$ & $\begin{array}{l}\text { N. } 23^{\circ} \mathrm{W} \text {. } \\
\text { Metavolcanic rocks } \\
\text { Permian and Triassic } \\
\text { isochron }\end{array}$ & 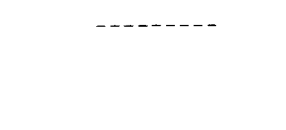 & ..... & $\begin{array}{l}\text { N. } 61^{\circ} \mathrm{W} . \\
\text { Same rocks }\end{array}$ \\
\hline $\begin{array}{l}\text { Northern Ritter Range } \\
\text { (Kistler, 1966a) }\end{array}$ & $\ldots \ldots$ & $\begin{array}{l}\text { N. } 25^{\circ} \mathrm{W} \text {. } \\
\text { Metavolcanic rocks } \\
\text { Permian and Triassic } \\
\text { isochron }\end{array}$ & $-\ldots-.--$ & ------ & $\begin{array}{l}\text { N. } 50^{\circ} \mathrm{W} . \\
\text { Same rocks }\end{array}$ \\
\hline $\begin{array}{l}\text { Pine Creek } \\
\text { (Bateman, 1965) }\end{array}$ & ----- & $\begin{array}{l}\mathrm{N} .22^{\circ} \mathrm{W} \text {. } \\
\text { Metasedimentary rocks } \\
\text { Pennsylvanian (?) and } \\
\text { Permian (?) }\end{array}$ & bordered by & Upper Triassic granite & $-\cdots--$ \\
\hline $\begin{array}{l}\text { Calaveras Formation } \\
\text { Stanislaus River } \\
\text { (Baird, 1962) }\end{array}$ & $-\cdots-$ & $\ldots \ldots$ & $\begin{array}{l}\text { N. } 60^{\circ} \text { E. } \\
\text { Slate, Pennsylvanian (?) } \\
\text { and Permian (?) }\end{array}$ & $\begin{array}{l}\text { N. } 25^{\circ} \mathrm{W} . \\
\text { Same rocks }\end{array}$ & -......- \\
\hline $\begin{array}{l}\text { Calaveras Formation } \\
\text { Merced River } \\
\text { (W. J. Nokleberg, } \\
\text { unpub. data, 1977) }\end{array}$ & $--\cdots-$ & $\cdots-\cdots$ & $\begin{array}{l}\text { N. } 40^{\circ} \mathrm{E} \text {. } \\
\text { Slate, Pennsylvanian (?) } \\
\text { and Permian (?) }\end{array}$ & $\begin{array}{l}\text { N. } 30^{\circ} \mathrm{W} . \\
\text { Same rocks }\end{array}$ & ------- \\
\hline $\begin{array}{l}\text { Boyden Cave (Girty, } \\
\text { 1977) }\end{array}$ & $\cdots+\cdots$ & $\ldots-\ldots$ & $\begin{array}{l}\text { N. } 60^{\circ} \text { E. } \\
\text { Metasedimentary rocks, } \\
\text { Upper Triassic and } \\
\text { Lower Jurassic }\end{array}$ & $\begin{array}{l}\mathrm{N} .20^{\circ} \mathrm{W} . \\
\text { Same rocks }\end{array}$ & 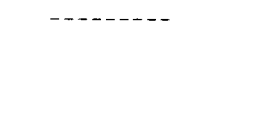 \\
\hline $\begin{array}{l}\text { Strawberry mine } \\
\text { (Nokleberg, 1970a, b) }\end{array}$ & $\ldots \ldots$ & -...-- & $\begin{array}{l}\text { Northeast } \\
\text { Metasedimentary rocks, } \\
\text { Lower Jurassic (?) }\end{array}$ & $\begin{array}{l}\text { N. } 30^{\circ} \text { W. } \\
\text { Metavolcanic rocks, } \\
\text { Lower Cretaceous } \\
\text { isochron }\end{array}$ & $\begin{array}{l}\text { N. } 60^{\circ} \mathrm{W} \text {. } \\
\text { Same rocks }\end{array}$ \\
\hline $\begin{array}{l}\text { Western metamorphic } \\
\text { belt, central and } \\
\text { western blocks } \\
\text { (Wetzel and Nokleberg, } \\
\text { 1976) }\end{array}$ & $-\cdots-\cdots$ & $\ldots \ldots$ & $\ldots-\ldots-$ & $\begin{array}{l}\text { N. } 20^{\circ}-40^{\circ} \mathrm{W} \text {. } \\
\text { Slates and greenschists } \\
\text { Upper Jurassic }\end{array}$ & $-\ldots-\ldots$ \\
\hline $\begin{array}{l}\text { Lower Kings River area } \\
\text { (Nokleberg, 1975) }\end{array}$ & -.....- & $\ldots-\ldots$ & --n-n- & $\begin{array}{l}\text { N. } 30^{\circ} \mathrm{W} . \\
\text { Deformed gabbros } \\
\text { Middle Jurassic } \\
\text { (Saleeby, 1974) }\end{array}$ & $\begin{array}{l}\text { N. } 60^{\circ} \mathrm{W} . \\
\text { Same rocks }\end{array}$ \\
\hline $\begin{array}{l}\text { Mineral King } \\
\quad \text { (Christensen, 1963) }\end{array}$ & $\ldots \ldots$ & -.....- & $-\cdots----$ & $\begin{array}{l}\text { N. } 30^{\circ} \mathrm{W} . \\
\text { Metasedimentary rocks } \\
\text { Upper Triassic fossils }\end{array}$ & $\begin{array}{l}\text { Encircled by Lower } \\
\text { Cretaceous granite }\end{array}$ \\
\hline $\begin{array}{l}\text { Mount Dana } \\
\text { (Kistler, 1966a, b; } \\
\text { Russell, 1976) }\end{array}$ & $\cdots-\cdots$ & $\begin{array}{l}\mathrm{N} \cdot 25^{\circ} \mathrm{W} . \\
\text { Metavolcanic rocks } \\
\text { Permian and Triassic } \\
\text { isochron }\end{array}$ & Angular unconformity & $\begin{array}{l}\text { N. } 30^{\circ} \mathrm{W} . \\
\text { Metavolcanic rocks } \\
\text { (lower part of Dana } \\
\text { sequence) } \\
\text { Jurassic isochron }\end{array}$ & $\begin{array}{l}\text { N. } 65^{\circ} \text { W. } \\
\text { Metavolcanic rocks (upper } \\
\text { part of Dana sequence) } \\
\text { Lower Cretaceous } \\
\text { isochron }\end{array}$ \\
\hline $\begin{array}{l}\text { Ritter Range } \\
\text { (Kistler, 1966a, b; } \\
\text { Huber and Rinehart, } \\
\text { 1965; Fiske and } \\
\text { Tobisch, 1978) }\end{array}$ & $\ldots \ldots$ & - - & -------- & $\begin{array}{l}\text { N. } 30^{\circ} \mathrm{W} \text {. } \\
\text { Metavolcanic rocks } \\
\text { Permian, Triassic, and } \\
\text { Lower Jurassic isochrons } \\
\text { and Pb-U zircon ages }\end{array}$ & $\begin{array}{l}\mathrm{N} .70^{\circ} \mathrm{W} . \\
\text { Metavolcanic rocks } \\
\text { Lower Cretaceous isochron } \\
\text { and } \mathrm{Pb}-\mathrm{U} \text { zircon ages }\end{array}$ \\
\hline
\end{tabular}

north or south within the axial planes in all roof pendants, indicate either a first or near-first deformation of these rocks. The double gently plunging maxima in the
Mount Morrison and Log Cabin mine roof pendants (figs. $2 B, 2 E$ ) may indicate superposition of these structures over broad northeast-striking folds. In the 
Dinkey Creek roof pendant the distribution of fold axes along the axial plane may represent a component of slip folding, or primary undulations in the axial surfaces of fold axes (Kistler and Bateman, 1966).

The orientations of poles to bedding in these rocks (figs. $2 C, 2 F, 2 G, 2 J$ ) yield less information than the fold axes and axial planes because the bedding was usually rotated into various attitudes during a single regional deformation, and later deformation caused considerably more scatter (Weiss, 1959). However, the Log Cabin mine and Dinkey Creek roof pendants (figs. $2 F, 2 J)$ show a relatively simple distribution of poles to bedding along a partial great circle that defines a subhorizontal fold axis plunging either north or south. Coincidence of this axis with the concentration of Devonian or Mississippian fold axes in the respective roof pendants (compare fig. $2 F$ with $2 E, 2 I$ with $2 J$ ) indicates that during this deformation the bedding was rotated into major folds of the same orientation as minor folds, and also that a strong component of flexural folding is present (Weiss, 1959). The Bishop Creek roof pendant (fig $2 G$ ) shows a distribution of poles to bedding along great circles that define a subhorizontal $\beta$-axis, gently plunging $8^{\circ}$ to azimuth $008^{\circ}-$ evidence of the first deformation of these rocks. The data on the Bishop Creek roof pendant are from the Mount Goddard geologic quadrangle, mapped by Bateman (1965). In the Mount Morrison roof pendant (fig. $2 C$ ) poles to bedding are distributed along partial great-circle girdles that define fold axes plunging gently to the northwest or southeast; the coincidence of these axes with later Mesozoic fold axes indicates subsequent deformation of the rocks.

\section{STYLE OF DEFORMATION}

Isoclinal folding during the Devonian or Mississippian regional deformation is shown by the parallel maxima of poles to bedding and poles to axial planes and schistosities (fig. 2), which indicate that fold limbs were parellel to axial planes; most of the areas shown in the structural diagrams (fig. 2) also possess isoclinal folds. Major thrust faults parallel to the major-fold axial planes, which were reported for the Mount Morrison, Dinkey Creek, and Log Cabin mine roof pendants (Kistler and Bateman, 1966; W. J. Nokleberg, unpub. data, 1976; Russell and Nokleberg, 1977), indicate that thrusting was contemporaneous with folding. In the Log Cabin mine roof pendant the axial plane thrusts dip as gently as $20^{\circ} \mathrm{W}$. and strike N. $5^{\circ} \mathrm{E}$. The gentle to moderate westward dips of axial planes and thrust faults in the Log Cabin mine and Dinkey Creek roof pendants and the presence of overturned asymmetric folds indicate tectonic transport from west to east.

Regional metamorphism coinciding with deforma- tion and causing formation of cataclasites, axial-plane schistosities, and lineations was reported by most of the above authors. Regional metamorphism of the greenschist facies is indicated in the Mount Morrison, Log Cabin mine, and Dinkey Creek roof pendants by the occurrence of such index minerals as epidote, chlorite, andalusite, and actinolite in appropriate-composition rocks that indicates recrystallization at relatively low temperature and shallow depth. In most roof pendants this regional metamorphism has been overprinted by one or more episodes of contact metamorphism during emplacement of granitic rocks. Most roof pendants are completely recrystallized to the hornblendehornfels facies on their edges, whereas the interiors of some large roof pendants still exhibit prior regionalgrade metamorphism.

\section{TIMING OF DEFORMATION AND REGIONAL CORRELATIONS}

The age of the Devonian or Mississippian regional deformation is best established in the fossiliferous Mount Morrison roof pendant, where metamorphosed miogeosynclinal rocks are subdivided into an Ordovician McGee Mountain block on the east, a central Silurian(?) Convict Lake block, and a Pennsylvanian and Permian(?) Bloody Mountain block on the west (Rinehart and Ross, 1964). A stratigraphic thickness of 9,600 m was established for what Rinehart and Ross (1964) interpreted as a homoclinal sequence, progressively younger to the west. Three generations of isoclinal folds, faults, and related structures were later recognized by Russell and Nokleberg (1977), who estimated the actual thickness to be $4,500 \mathrm{~m}$ or less. North-striking structures of the first generation occur only in the Ordovician and Silurian(?) rocks, whereas the general occurrence of structures of all later generations in blocks of all rock ages limits the time of first deformation to the Devonian or Mississippian (table 1). An angular unconformity, now defined by the LaurelConvict fault, separates Ordovician and Silurian(?) from Pennsylvanian and Permian(?) rocks (Rinehart and Ross, 1964; Russell and Nokleberg, 1977), and older thrice-deformed from younger rocks containing only the last two generations of structures.

To the south the Bishop Creek roof pendants contain north-striking Devonian or Mississippian folds (fig. $2 G$ ) and Ordovician or Silurian graptolites, recently found in the Coyote Flat area by J. N. Moore (oral commun., 1976). The similarity between rock types, ages, and structures in the Mount Morrison and Bishop Creek roof pendants is strong evidence of codeformation during the Devonian or Mississippian. The similarity between rock types and structures in the Mount Morrison roof pendant and in the Log Cabin mine and Dinkey Creek roof pendants, as well as the observation 


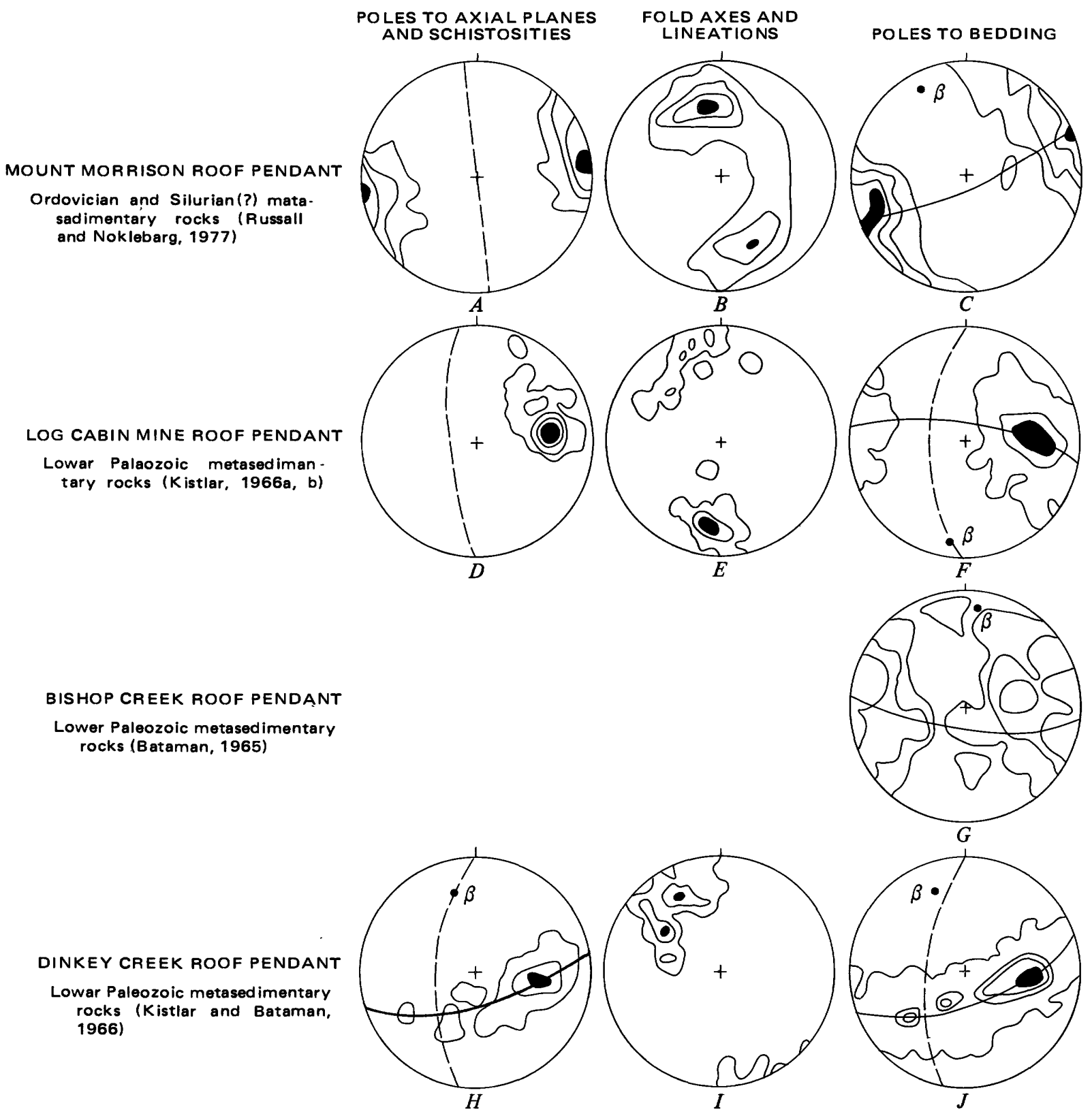

Figure 2.-Structural diagrams for areas deformed along northward trends during the Devonian or Mississippian. Data are from Ordovician and Silurian(?) or lower Paleozoic rocks of high Sierra Nevada roof pendants. Dashed great circles, average maximum attitude of axial planes, schistosities, or bedding; solid great circles, girdles of poles to axial planes and schistosities, or to bedding; b, major-fold axes, defined as poles to girdles. Contour data are listed in table 2 .

that this was their first intense deformation, indicates that these roof pendants were codeformed during the Devonian or Mississippian, coincident with the Antler orogeny in the Great Basin (Russell and Nokleberg, 1977). The structures in the central Sierra Nevada and in the Antler orogenic belt are all due to compression and include folds, thrust faults, lineations, and schistosities. Asymmetric folds and thrust faults in the Log Cabin mine and Dinkey Creek roof pendants indicate tectonic transport from west to east, analogous to the
Antler orogeny, in which Cambrian and Devonian eugeosynclinal sedimentary rocks were thrust eastward over miogeosynclinal sedimentary rocks of similar age along the Roberts Mountain thrust during the Late Devonian (Burchfiel and Davis, 1972).

\section{PERMIAN AND TRIASSIC UPLIFT, EROSION, AND ANDEAN-TYPE VOLCANISM}

The Devonian or Mississippian regional deformation is separated from later deformations by a period of, 
TABLE 2.-Data for figure 2

\begin{tabular}{crl}
\hline Diagram & Points & \multicolumn{1}{c}{$\begin{array}{c}\text { Contours } \\
\text { (percent per 1 percent area) }\end{array}$} \\
\hline A & 144 & $0.7,3.5,7,10$ \\
B & 98 & $1,5.1,10,15.3$ \\
C & 176 & $0.6,2,6,10$ \\
D & 23 & $4.4,5,10,20$ \\
F & 29 & $3.3,10,20$ \\
G & 172 & $0.6,5,10$ \\
H & 178 & $0.6,1.1,2.2,4.5$ \\
I & 58 & $1.7,10,15$ \\
J & 33 & $3.3,10,20$ \\
L & 364 & $0.35,4,5,10$ \\
L & 75 & $1,5,20,40$ \\
M & 75 & $1,4,8,10$ \\
\hline
\end{tabular}

successively: deposition; uplift, erosion, and tilting; and, finally, onset of Andean-type volcanism. These events are recorded by an angular unconformity between a sequence of lower or upper Paleozoic metasedimentary rocks and of Permian and Triassic metavolcanic and volcanic-derived sedimentary rocks named the Koip sequence (Kistler, 1966a). This unconformity occurs along a $75-\mathrm{km}$ stretch of the Sierra Nevada crest that includes the Saddlebag Lake roof pendant (Brook, 1972, 1977), the Mount Dana roof pendant (Russell, 1976), the northern part of the Ritter area of the Ritter Range roof pendant (Kistler, 1966a), and the Mount Morrison roof pendant (Russell and Nokleberg, 1977). Interpretation of the contact between these two sequences as an angular unconformity rather than a fault is discussed by Morgan and Rankin (1972) and Brook, Nokleberg, and Kistler (1974).

The Permian and Triassic age of uplift, tilting, and erosion is indicated by Pennsylvanian and Permian(?) rocks of the Mount Morrison roof pendant, which are the youngest rocks underlying the unconformity; and by Permian and Triassic rocks of the Saddlebag Lake and Ritter Range areas, which are the oldest rocks overlying the unconformity. A Permian age for this angular unconformity coincides with the Sonoman orogeny and related Golconda thrusting in the Great Basin (Silberling and Roberts, 1962; Speed, 1971). In the area where the Koip sequence overlies Ordovician and Silurian(?) metasedimentary rocks, uplift and erosion could have occurred at any time between the Silurian(?) and Triassic. In any case, volcanism began in the Permian and Triassic with formation of the Koip sequence, which gave a $\mathrm{Rb}$-Sr whole-rock isochron of 240 m.y. (Kistler, 1966a; Brook, 1972, 1977). Although development of the unconformity has been tentatively correlated with the Sonoman orogeny, continuation of the Golconda thrust has not yet been found in the central Sierra Nevada. Our knowledge of this unconfor- mity is important because the contact represents a major change in the stratigraphy and structure of the wallrocks that occurred immediately before the early stages of Andean-type volcanism and of emplacement of the magmas that formed the massive Sierra Nevada batholith.

\section{MESOZOIC DEFORMATIONS}

\section{AREAL EXTENT}

Geologic evidence is found for several Mesozoic regional deformations in the central Sierra Nevada (table 1). The first and oldest Mesozoic deformation oc. curred along N. $20^{\circ}-40^{\circ} \mathrm{W}$. trends during the Triassic and is defined by the folding and faulting of Permian and Triassic metavolcanic rocks of the Saddlebag Lake and northern Ritter Range roof pendants, and of Pennsylvanian(?) and Permian(?) metasedimentary rocks of the Pine Creek roof pendant; and by tilting or folding of the eastern part of the Calaveras Formation in the western metamorphic belt. A Jurassic regional deformation occurred along N. $30^{\circ}-60^{\circ} \mathrm{E}$. trends in the Calaveras Formation and is superposed on older northwest-striking structures. A later Mesozoic regional deformation is the classic Nevadan orogeny of Late Jurassic age that deformed the western metamorphic belt and roof pendants in the batholith (table 1). The Nevadan orogeny is preserved in the western metamorphic belt as a fault-fold system, striking $\mathrm{N}$. $20^{\circ}-40^{\circ} \mathrm{W}$., that contains large- and small-scale faults, asymmetric folds, and zones of melange. The Nevadan orogeny can be identified with certainty only in the Mineral King, Ritter Range, Mount Dana, and Boyden Cave roof pendants, although many other roof pendants, including the Mount Morrison, Saddlebag Lake, and Dinkey Creek roof pendants, contain structures of similar trend and style that can only be dated as ranging from Triassic to Early Cretaceous. A still-later Mesozoic regional deformation occurred along N. 50 $80^{\circ} \mathrm{W}$. trends during the Early or early Late Cretaceous in several widely separated roof pendants and in areas of the western metamorphic belt that definitely include the Strawberry mine and Ritter Range roof pendants, in the lower Kings River area, and probably in the Mount Morrison, Dinkey Creek, Saddlebag Lake, and Bishop Creek roof pendants.

\section{TRIASSIC REGIONAL DEFORMATION OF HIGH-COUNTRY ROOF PENDANTS}

\section{ORIENTATION AND STYLE OF STRUCTURES}

An intense deformation along N. $20^{\circ}-30^{\circ} \mathrm{W}$. trends is recorded in the Koip and Lewis sequences of the Saddlebag Lake and northern Ritter Range roof pendants (Kistler, 1966a; Brook, 1972, 1977), and in upper 
Paleozoic(?) metasedimentary rocks of the Pine Creek roof pendant (fig. 1, table 1). The diagrams of poles to axial planes and schistosities for this deformation (fig. 3 , table 3 ) show average strikes of $\mathrm{N} .20^{\circ}-30^{\circ} \mathrm{W}$. and vertical dips (dashed great circle, fig. $3 \mathrm{~A}$; dashed great circle 1 , fig. $3 D$ ). In the northern Ritter Range roof pendant (figs. $3 D-3 F$ ) the partial spread of poles to axial planes along a great circle, and a concentration of axial planes along $\mathrm{N} .60^{\circ}-70^{\circ} \mathrm{W}$. trends (dashed great circle 2), are attributed to a later early Late Cretaceous deformation. In the Saddlebag Lake roof pendant (figs. $3 A-3 C$ ) fold axes and lineations formed during the Triassic deformation plunge moderately to steeply northwest within the $\mathrm{N} .20^{\circ}-30^{\circ} \mathrm{W}$. axial planes (fig. $3 B$ ). In the northern Ritter Range roof pendant, fold axes of this and a later deformation, which are plotted together, plunge primarily along N. $60^{\circ} \mathrm{W}$.-striking axial planes (fig. $3 E$ ). Kistler (1966a) showed that the
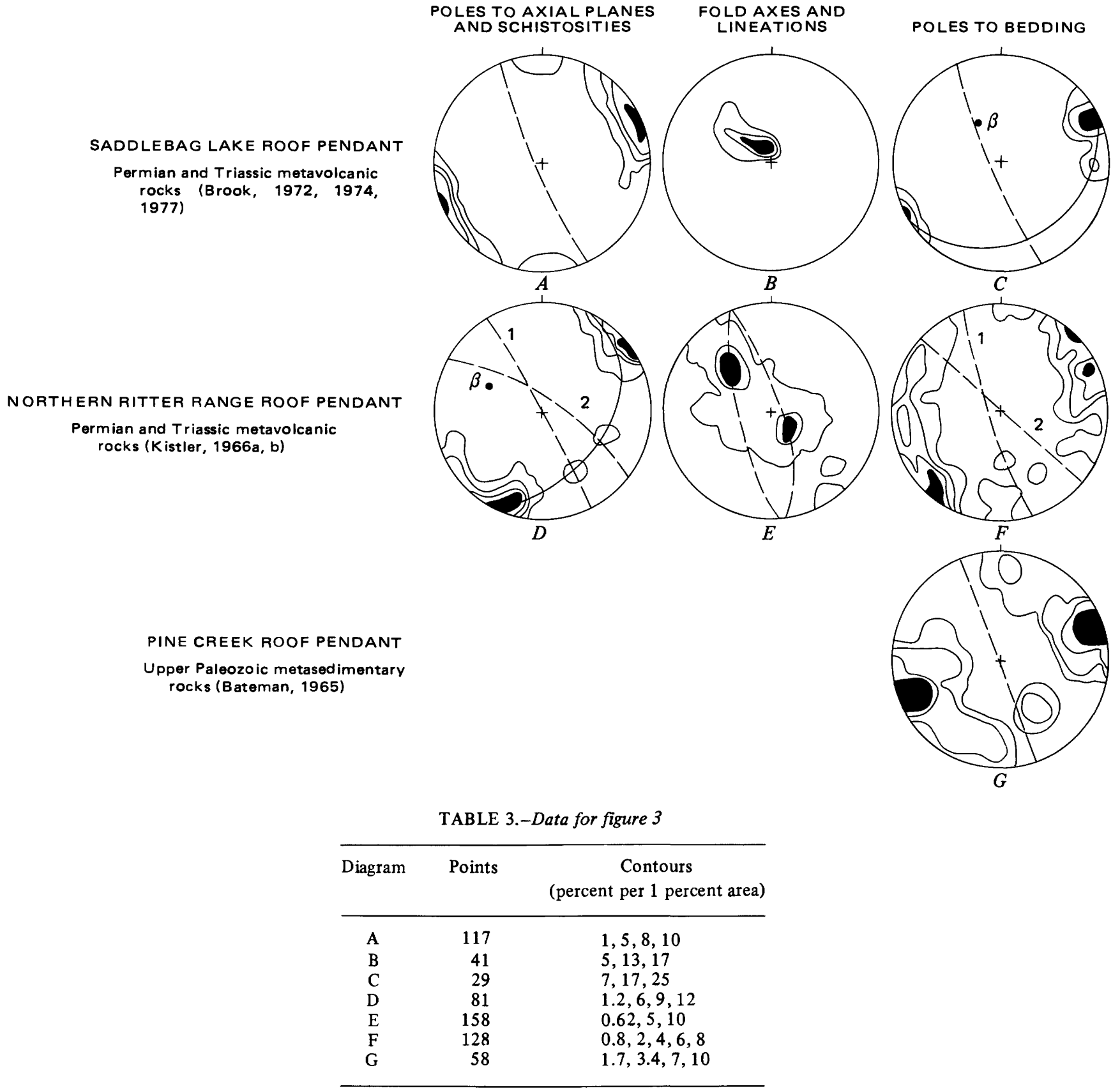

TABLE 3.-Data for figure 3

Figure 3.-Structural diagrams for three high-Sierra Nevada roof pendants deformed during the Triassic Period along N. $20^{\circ}-30^{\circ}$ W. trends. See figure 2 for explanation. Contour data as shown. 
later formed fold axes are superposed on the limbs of $\mathrm{N}$. $20^{\circ}-30^{\circ} \mathrm{W}$.-striking folds of Triassic age (dashed great circle, fig. $3 E$ ).

The diagrams of poles to bedding (figs. $3 C, 3 F, 3 G$ ) show the rotation of bedding to steep dips, with average strikes of $\mathrm{N} .20^{\circ}-30^{\circ} \mathrm{W}$. in all three areas. In the northern Ritter Range roof pendant a secondary maximum of bedding occurs along $\mathrm{N}$. $60^{\circ} \mathrm{W}$. strikes, with a near-vertical dip (dashed great circle 2, fig. $3 F$ ) that also reflects later deformation. In the Saddlebag Lake roof pendant a weak distribution of bedding poles occurs along a great circle that defines a $\beta$-axis plunging moderately northwest, with a $20^{\circ}-30^{\circ} \mathrm{W}$.-striking axial plane (fig. $3 C$ ) parallel to the maxima of fold axes and lineations (fig. $3 B$ ). Upper Paleozoic metasedimentary rocks of the Pine Creek roof pendant (fig. $3 G$ ) contain large folds, with axial planes striking N. $20^{\circ}-$ $30^{\circ} \mathrm{W}$, and steep dips, as shown on the Mount Goddard geologic quadrangle map (Bateman, 1965). The diagram of poles to bedding for this area (fig. $3 G$ ) also shows rotation of beds into steep dips, with N. $20^{\circ}-30^{\circ}$ W. strikes.

In both the Saddlebag Lake and northern Ritter Range roof pendants the Triassic deformation of the Koip and Lewis sequences was an intense event that gave rise to isoclinal folds, parallel faults, and regional metamorphism. Isoclinal folding is shown by field evidence, by parallel maxima of poles to bedding and to axial planes (fig. 3), and by cross sections of folds in the Saddlebag Lake roof pendant (Brook, 1972, 1977). Major high-angle faults paralleling the axial planes are shown on geologic maps of the two areas (Kistler, 1966b; Brook, 1972, 1977). The upright nature of folds and the near-vertical dip of associated faults indicate mainly compression during this deformation and little tectonic transport of one plate over another. In both roof pendants, regional metamorphism coincided with deformation and included formation of cataclasites, axial-plane schistosities, and lineations (Kistler, 1966a, b; Brook, 1972, 1977). Regional metamorphism occurred under conditions of the greenschist facies with the crystallization of such index minerals as andalusite, chlorite, and epidote (Kerrick, 1960; Brook, 1972). In both roof pendants, regional metamorphism was overprinted by two periods of contact metamorphism associated with emplacement of Late Triassic and Late Cretaceous granitic rocks (Kistler, 1966a).

TIMING OF DEFORMATION AND REGIONAL CORRELATIONS

The Koip sequence is dated Permian and Triassic (240 m.y.) by a Rb-Sr whole-rock isochron (Kistler, 1966a; Brook, 1972, R. W. Kistler, unpub. data, 1977). Structures in the sequence are intruded by Late Trias- sic granitic rocks of the Lee Vining intrusive epoch (Evernden and Kistler, 1970); these relations bracket the intense deformation of the Koip and older sequences as Early and Middle Triassic. The age of this deformation can also be determined from the Pine Creek roof pendant, where N. $20^{\circ}-30^{\circ}$ W.-striking structures in Pennsylvanian(?) and Permian(?) metasedimentary rocks are crosscut by relatively undeformed Late Triassic (210 m.y. old) granitic rocks of the Lee Vining intrusive epoch; this relation restricts the deformation to the Late Permian or Triassic.

In the Calaveras. Formation of the western metamorphic belt is evidence for two pre-Nevadan deformations, the earlier of which occurred along $\mathrm{N}$. $20^{\circ}-40^{\circ} \mathrm{W}$. trends and is expressed by a northwesttrending form surface, dipping moderately northeast, upon which later folds are superposed (Baird, 1962; W. J. Nokleberg, unpub. data, 1976). This earlier deformation is possibly the same as the Triassic deformation of the high-country roof pendants. The eastern part of the Calaveras Formation contains abundant metaquartzite and meta(quartz-rich)siltstone, designated chert by Clark (1964), that were designated the Shoo Fly Formation(?) (fig. 1) by Schweickert (1978). In the following discussion the Shoo Fly(?) is included in the Calaveras Formation.

\section{EARLY AND MIDDLE JURASSIC REGIONAL DEFORMATION}

\section{ORIENTATION AND STYLE OF STRUCTURES}

The upper Paleozoic Calaveras Formation, which is intensely deformed along $\mathrm{N} .30^{\circ}-50^{\circ} \mathrm{E}$. trends in a large area from the Stanislaus to the Merced Rivers (fig. 1, table 1), exhibits melange, broken formation, cataclasites, and isoclinal to open folds (Wetzel and Nokleberg, 1976). These structures, superposed on older northwest-striking structures (Baird, 1962; W. J. Nokleberg, unpub. data, 1976), occur in slate, metasiltstone, marble, and metabasalt commonly included in the Calaveras Formation but possibly containing rocks of a wide range of ages and origins (Clark, 1964). The melange character of the Calaveras Formation along the Stanislaus and Tuolumne Rivers has also been observed by Schweikert and Cowan (1975). The diagrams of poles to axial planes and schistosities for this deformation (fig. 4, table 4) show an average orientation of $\mathrm{N}$. $30^{\circ}-60^{\circ} \mathrm{E}$. over a wide terrain (figs. $4 A, 4 D, 4 G, 4 J$ ). In structures of the greenschist east of the Melones fault on the Stanislaus River (fig. $4 D$ ) the poles to axial planes are distributed along a great circle, with a secondary maximum of axial planes and schistosities trending $\mathrm{N} .30^{\circ} \mathrm{W}$. and dipping steeply west that is due to the later Late Jurassic Nevadan orogeny (Baird, 1962). Fold axes and 


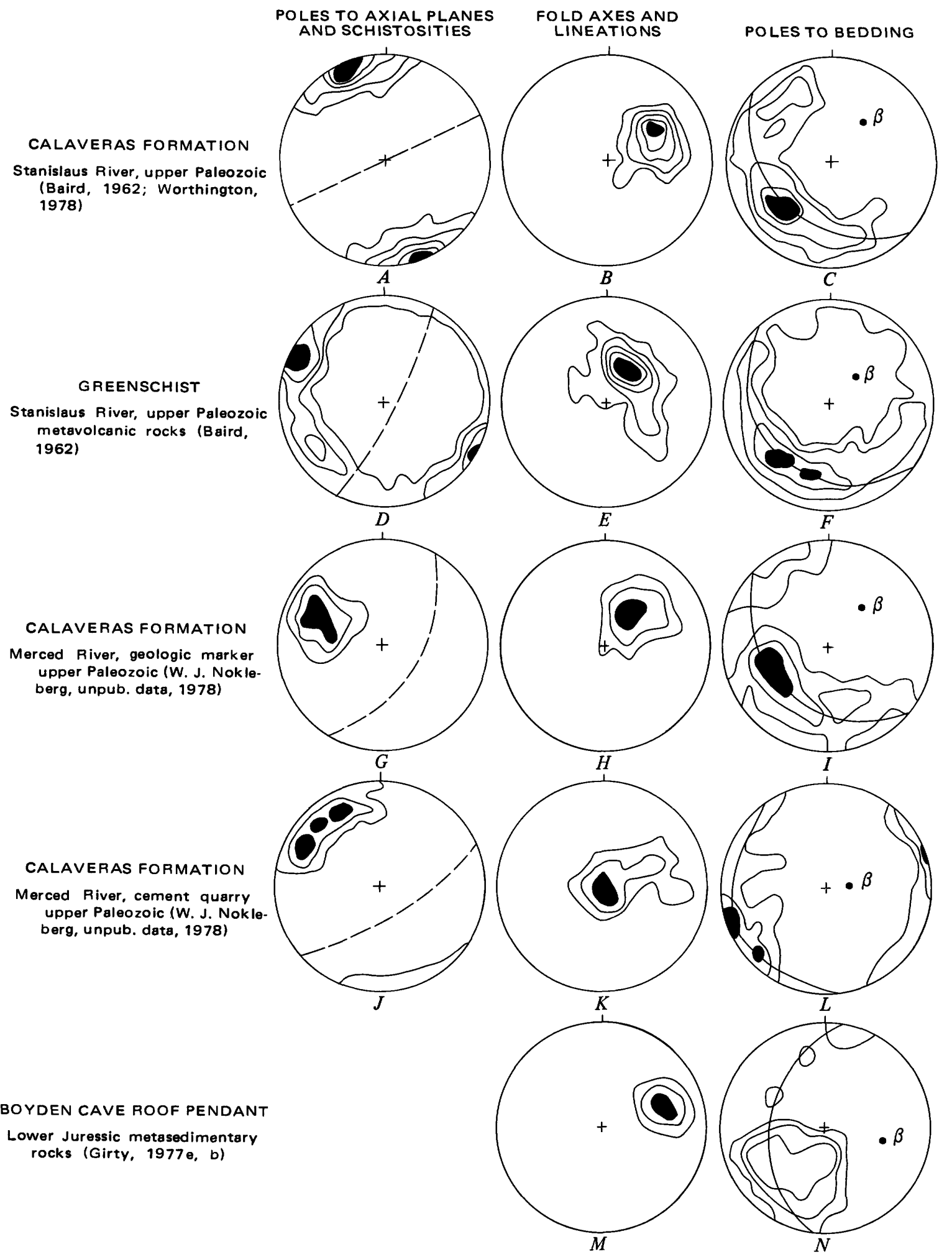

Figure 4.-Structural diagrams for parts of the Calaveras Formation in the western metamorphic belt deformed during the Late Triassic and Middle Jurassic along N. $30^{\circ}-60^{\circ}$ E. trends. See figure 2 for explanation. Contour data in table 4.

lineations show a remarkable parallel orientation, with maxima plunging generally $30^{\circ}-80^{\circ}$ at azimuths between $030^{\circ}$ and $060^{\circ}$ (figs. $4 B, 4 E, 4 H, 4 K$ ). In all areas the diagrams of poles to bedding show a distinct girdle that defines $\beta$-axes plunging moderately to steeply northeast, parallel to the concentrations of fold 
TABLE 4.-Data for figure 4

\begin{tabular}{ccc}
\hline Diagram & Points & $\begin{array}{c}\text { Contours } \\
\text { (percent per 1 percent area) }\end{array}$ \\
\hline A & 125 & $1,4,8,12,16$ \\
B & 117 & $1,5,10,20$ \\
C & 170 & $1,2,4,6,8,12$ \\
D & 71 & $1,2,8,12$ \\
E & 133 & $1,4,8,12,16$ \\
F & 178 & $1,2,3,5,6,8$ \\
G & 42 & $1,4,8,12$ \\
H & 58 & $1,8,16$ \\
I & 157 & $0.2,2,6$ \\
J & 41 & $1,5,10$ \\
K & 35 & $1,5,15$ \\
L & 34 & $1,2,4,8$ \\
M & 10 & $1,5,7$ \\
N & 42 & $1,5,10$ \\
\hline
\end{tabular}

axes and lineations in each area (figs. $4 C, 4 F, 4 I, 4 L$ ); this feature indicates that the major, like the minor, folds plunge moderately to the northeast at nearly right angles to strike of the batholith and range (Wetzel and Nokleberg, 1976).

The style of structures varies from the Stanislaus River in the north to the Merced River in the south, where cataclasis is much less intense and folds much more frequent than along the Stanislaus River. The folds along the Merced River are strongly asymmetric, probably because of superposition over the older northwest-trending form surface (W. J. Nokleberg, unpub. data, 1976). This deformation is associated with regional metamorphism that included formation of schistosities, lineations, and partly recrystallized cataclasites; recrystallization occurred under conditions of the greenschist facies (W. J. Nokleberg, unpub. data, 1976).

The Boyden Cave roof pendant, along the west side of the batholith (fig. 1), contains an older generation of structures remarkably similar in style, geometry, and orientation to those in the Calaveras Formation. Cataclastic calc-silicate hornfels is intensely deformed along N. $60^{\circ}$ E. trends (table 1), with open to isoclinal folds, schistosities, and melange (Girty, 1977a, b). The fold-axial planes strike N. $60^{\circ} \mathrm{E}$., with fold axes and lineations plunging moderately at azimuth $060^{\circ}$ (fig. $4 M$ ). Bedding in this unit is rotated around a $\beta$-axis that plunges moderately at azimuth $090^{\circ}$ (fig. $4 N$ ) and nearly coincides with the fold axes (fig. $4 N$ ).

Metasedimentary rocks of the Strawberry mine roof pendant, in the center of the batholith (fig. 1), contain the oldest generation of structures, consisting of major northeast-trending folds and associated minor isoclinal folds (Nokleberg, 1970a, b; W. J. Nokleberg, unpub. data, 1977). The orientation and style of these structures are similar to those of older structures in the
Boyden Cave roof pendant. These metasedimentary rocks of the Strawberry mine roof pendant, of probable Early Jurassic age, are similar to Upper Triassic and Lower Jurassic metasedimentary rocks of the Boyden Cave and Mineral King roof pendants, which compose the Kings sequence of Bateman and Clark (1974).

\section{TIMING OF DEFORMATION AND REGIONAL CORRELATIONS}

A maximum age for the Early and Middle Jurassic regional deformation is indicated by: (1) probable Middle Triassic deformation of the upper Paleozoic Calaveras Formation; (2) Lower Jurassic fossils (Jones and Moore, 1973) in cataclasites of the Boyden Cave roof pendant (Girty, 1977a, b); and (3) probable Lower Jurassic metasedimentary rocks of the Strawberry mine roof pendant (W. J. Nokleberg, unpub. data, 1977). A minimum age for this deformation is indicated by Late Jurassic metamorphic rocks of the western metamorphic belt, which were codeformed with the Calaveras Formation during the Late Jurassic Nevadan orogeny (Wetzel and Nokleberg, 1976). Thus the deformation of the Calaveras Formation and of the Boyden Cave roof pendant along N. $30^{\circ}-60^{\circ} \mathrm{E}$. trends is bracketed as Early or Middle Jurassic.

A significant aspect of Sierra Nevada tectonics is the divergence of northeast-trending structures in the Calaveras Formation from the northwest-trending batholith. These northeast-trending folds, shear zones, and schistosities may have formed during northwestsoutheast compression associated with left-lateral shear displacement along the western Sierra Nevada during the Middle Jurassic, as suggested by Silver and Anderson (1974) and Kistler and Peterman (1978). This displacement is defined by displacement of both Precambrian crystalline terranes and Paleozoic depositional trends from southeastern California to Sonora, Mexico (Silver and Anderson, 1974).

\section{NEVADAN OROGENY IN THE WESTERN METAMORPHIC BELT}

Deformational structures resulting from the Late Jurassic Nevadan orogeny in the western metamorphic belt consist of the Foothills fault system, which comprises the Melones and Bear Mountain faults, numerous smaller faults and shear zones, melange zones (Duffield and Sharp, 1975), and large folds that, according to Clark $(1960,1964)$, have essentially horizontal axes and wide homoclinal belts, with axial planes striking northwest and dipping steeply east, parallel to the Foothills fault system and apparently older than the faulting. Measurements of top directions in Mesozoic rocks of the western metamorphic belt, which 
show that 70 percent of the beds face east, define thereby the west limb of a large synclinorium (Bateman and Clark, 1974).

The Melones and Bear Mountain faults divide the western metamorphic belt into three blocks: (1) an eastern block consisting chiefly of the upper Paleozoic Calaveras Formation, and (2) central and (3) western blocks consisting chiefly of serpentinized peridotite, greenschist (predominantly metabasalt), and slate with subordinate graywacke in an older-to-younger age sequence. The assemblage in the central and western blocks was considered oceanic lithosphere by Wetzel and Nokleberg (1976), accreted island-arc volcanic and sedimentary rocks by Schweikert and Cowan (1975) and Moores (1970), and (or) dismembered ophiolite sequences representing slabs of oceanic crust on which island-arc volcanic rocks were deposited (Bateman and Clark, 1974).

\section{ORIENTATION AND STY'LE OF STRUCTURES}

A recent structural and tectonic analysis of the western metamorphic belt (Wetzel and Nokleberg, 1976) shows that the Late Jurassic Nevadan orogeny produced a fault-fold system, striking N. $20^{\circ}-40^{\circ} \mathrm{W}$. and dipping steeply east, that contains asymmetric folds, melange zones, and cataclasites. The major and minor folds plunge steeply to the southeast, parallel to lineations in the fault and melange zones. Movement on this fault-fold system consisted mostly of right-lateral strike-slip with a smaller component of reverse dipslip. The diagrams of poles to axial planes and schistosities for this deformation (fig. 5, table 5) show almost uniform N. $20^{\circ}-40^{\circ} \mathrm{W}$. strikes and steep eastward dips parallel to strike and dip of the Foothills fault system (figs. $5 A, 5 D, 5 G, 5 J, 5 M$ ); these orientations also occur in the discontinuous extension of the belt to the southeast along the lower Kings River area (Nokleberg, 1975). The parallelism of folds, faults, schistosities, shear zones, melanges, and cataclasites indicates that these structures represent a single generation of codeformed structures resulting from a common stress field. The diagrams for the Calaveras Formation in the Angels Camp to Sonora area (figs. $5 A-5 C$ ) and for large serpentinite in the lower Kings River area (figs. $5 M, 5 N$ ) show rotation of the older axial planes and schistosities into orientations parallel to the Foothills fault-fold system. The diagrams of fold axes and lineations (figs. $5 B, 5 E, 5 H, 5 K, 5 N$ ) show well-defined maxima plunging steeply to the east in the northern part of the belt and to the southeast in the central and southern parts. The east-plunging maximum of fold axes and lineations in the Angels Camp to Sonora area (fig. $5 B$ ) represents rotated Late Triassic and Middle Jurassic fold axes.
TABLE 5.-Data for figure 5

\begin{tabular}{crl}
\hline Diagram & Points & $\begin{array}{c}\text { Contours } \\
\text { (percent per 1 percent area) }\end{array}$ \\
\hline A & 121 & $1,2,4,6,8$ \\
B & 32 & $1,2,4,6$ \\
C & 35 & $1,2,6,8$ \\
D & 59 & $1,2,5,10$ \\
E & 30 & $1,2,5,10$ \\
F & 20 & $1,2,5$ \\
G & 35 & $2.9,6,10,14$ \\
H & 52 & $2,7,12,17$ \\
I & 450 & $0.4,2,4,6$ \\
J & 95 & $1,2,6,10$ \\
K & 42 & $1,2,6,18$ \\
L & 63 & $1,2,4,6$ \\
M & 78 & $1,2,4$ \\
N & 56 & $1,4,12$ \\
\hline
\end{tabular}

The diagrams of poles to bedding (figs. $5 C, 5 F, 5 I$, $5 L$ ) show well-defined great circles that in turn define a single $\beta$-axis of major folding in each area. The $\beta$-axes generally plunge steeply to moderately east or southeast and mostly coincide with the concentrations of minor-fold axes and lineations. The moderate to steep plunges of major- and minor-fold axes indicate few, if any, folds with subhorizontal axes in the western metamorphic belt. The southeastward plunge of fold axes and the compressive nature of reverse faulting and folding indicate a combination of right-lateral strike-slip and reverse dip-slip movements in the Foothills fault-fold system (Wetzel and Nokleberg, 1976). A component of right-lateral strike-slip motion is also indicated by the asymmetry of major folds, with longer east and shorter west limbs (Wetzel and Nokleberg, 1976), as shown on the California State Geologic Map, published by the California Division of Mines and Geology, and on geologic maps of the Angels Camp and Sonora quadrangles by Eric, Stromquist, and Swinney (1955).

The nature of folding from the Nevadan orogeny is also illustrated by a plot of poles to bedding with top directions for Mesozoic rocks of the western metamorphic belt (fig. 6, table 6), which shows: (1) a strong girdle of poles to beds that defines a single $\beta$-axis plunging moderately southeast, (2) no distinct girdle of poles to bedding defining a subhorizontal axis, (3) beds in the core of folds facing toward the southeast, and (4) mainly isoclinal folding with opposing top directions on the limbs of folds.

Low-grade regional metamorphism coincided with folding, faulting, and cataclasis during the Nevadan orogeny. Throughout most of the central and western parts of the belt, pervasive greenschist facies recrystallization has occurred with formation of such diagnostic minerals as epidote, chlorite, albite, and actinolite 
CALAVERAS FORMATION

Angels Camp and Sonora, upper Paleozoic (Eric and others, 1955)

PENON BLANCO VOLCANICS

Same area,Triassic or Jurassic (Eric and others, 1955)
MARIPOSA FORMATION

Northwest of Mariposa, Upper Jurassic slate (Best, 1963)
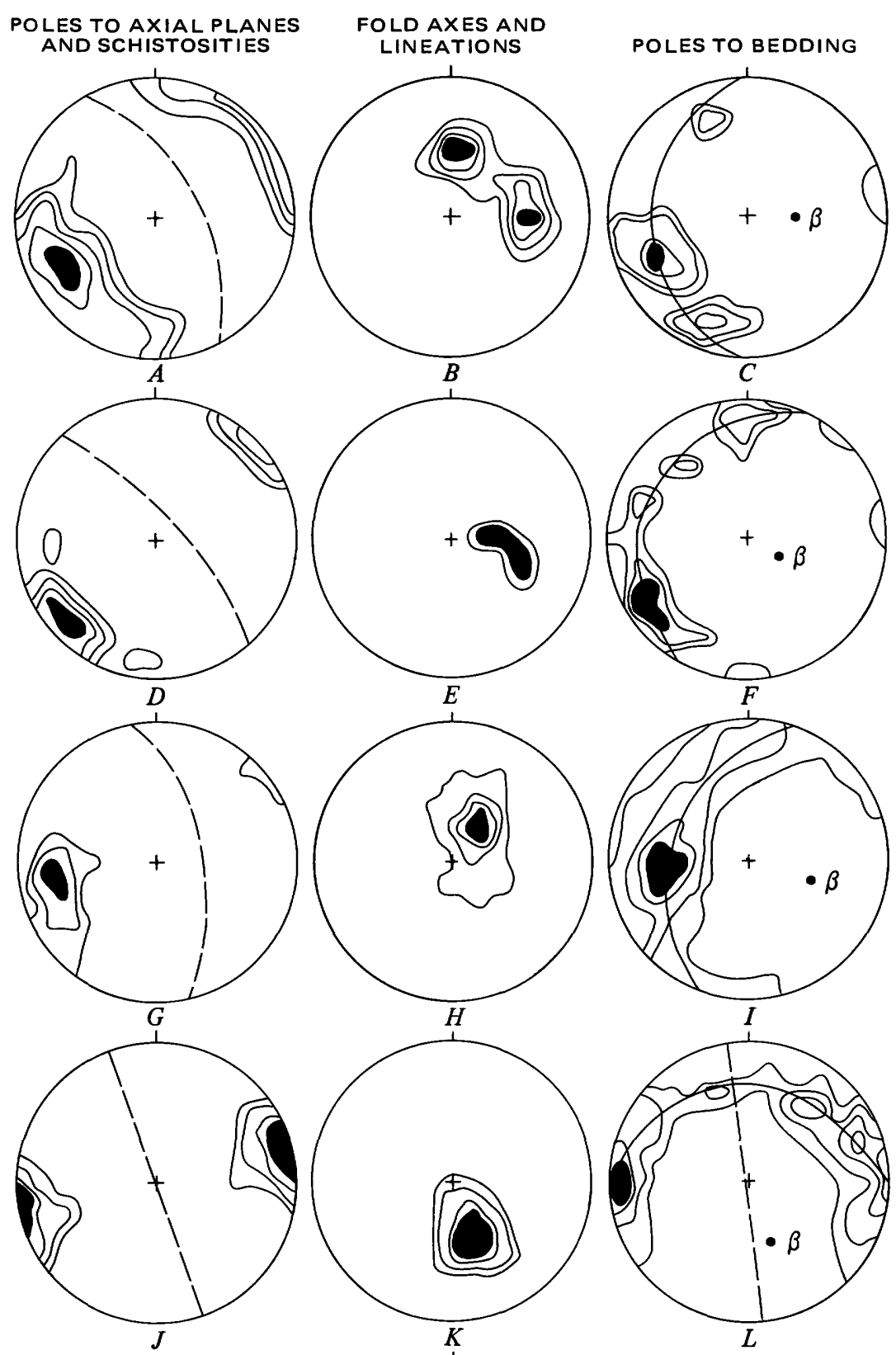

\section{LOWER KINGS RIVER ROOF PENDANT}

Matasedimentary rocks Calaveras Formation (?), upper Paleozoic(?) (Nokleberg, 1975)

LOWER KINGS RIVER ROOF PENDANT Serpentinite, Permian and Triassic (Noklaberg, 1975)
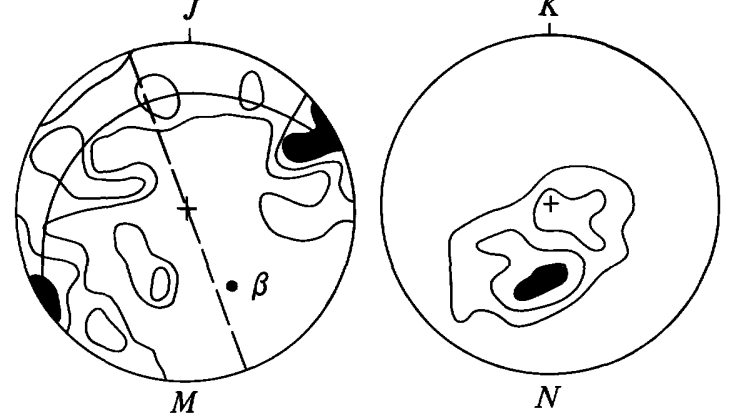

FIGURE 5.-Structural diagrams for areas of the western metamorphic belt deformed during the Nevadan orogeny along N. $20^{\circ}-40^{\circ} \mathrm{W}$. trends. See figure 2 for explanation. Contour data in table 5.

(Bateman and others, 1963; Clark, 1964; W. J. Nokleberg, unpub. data, 1976). Around some large Late Jurassic plutons, a higher facies formed. Along the west margin of the Guadalupe igneous complex of Best (1963) south of the Merced River, syntectonic growth of almandine, cordierite, hornblende, and biotite in 


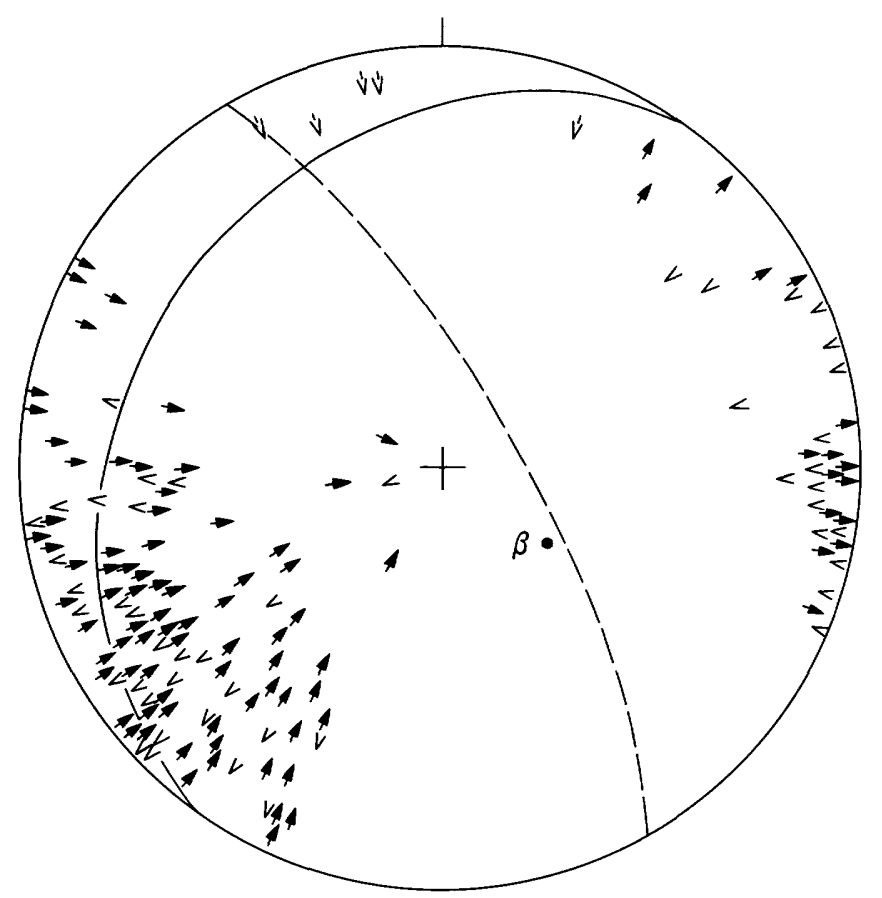

TABLE 6.-Data sources for figure 6

\begin{tabular}{ll}
\hline \multicolumn{1}{c}{ Area } & \multicolumn{1}{c}{ Authors } \\
\hline $\begin{array}{l}\text { River maps from Cosumnes to Merced } \\
\text { Rivers }\end{array}$ & Clark (1964) \\
$\begin{array}{l}\text { Mesozoic wallrocks, Amador County } \\
\text { Mesozoic wallrocks, San Andreas } \\
\text { quadrangle }\end{array}$ & $\begin{array}{l}\text { Duffield and Sharp (1975) } \\
\text { Clark (1970) }\end{array}$ \\
\end{tabular}

Figure 6.-Structural diagram of poles to bedding with top directions for Upper Jurassic country rocks of the western metamorphic belt. Solid arrow $(\rightarrow$ ) represents pole to bed facing east. Open arrow $(>$ ) represents pole to bed facing west or southwest. Open arrow with tail $(\rightarrow)$ represents pole to bed facing south. Arrows pointing toward center of diagram indicate upright beds; arrows pointing toward edge of net indicate overturned beds. See figure 2 for explanation.

strongly foliated schist and cataclasites indicates recrystallization under conditions of the upper amphibolite facies (W. J. Nokleberg, unpub. data, 1976). Apparently this pluton intruded during the waning stages of the Nevadan orogeny and thereby formed a higher grade regional facies than elsewhere.

\section{IIMING OF DEFORMATION AND REGIONAL CORRELATIONS}

The Nevadan orogeny was a short-lived but extremely intense deformation that occurred in the Late Jurassic between the early Kimmeridgian and late Tithonian Stages and spanned probably less than 5 m.y. (Bateman and Clark, 1974). This short timespan is defined by a Kimmeridgian age on the youngest de- formed rocks of the central and western blocks, and by a Late Jurassic age on crosscutting granitic rocks of the Yosemite intrusive epoch (Evernden and Kistler, 1970). The Guadalupe igneous complex of Best (1963), emplaced during the Yosemite intrusive epoch, crosscuts the western metamorphic belt nearly perpendicularly just west of Mariposa, Calif.

The foothills fault-fold system may represent a short-lived subduction zone. Schweikert and Cowan (1975) claimed that the faults are similar to those in the Franciscan Complex of Berkland and others (1972) that similarly juxtapose rocks having no apparent stratigraphic or deformational relations with one another. Wetzel and Nokleberg (1976) argued that the fault-fold system is not a subduction zone (1) because of the short-lived nature of the Nevadan orogeny and the extent of right-lateral strike-slip movement in the Foothills fault system, and (2) because the fault system crosscuts pre-Early Jurassic plutons and is in turn crosscut by Late Jurassic plutons (Evernden and Kistler, 1970). An alternative view is that the fault-fold system was the locus of telescoping and accreting of oceanic lithosphere onto the continental margin in response to the beginning of oblique subduction farther west (Wetzel and Nokleberg, 1976).

\section{JURASSIC AND EARLY CRETACEOUS REGIONAL DEFORMATIONS OF HIGH-COUNTRY ROOF PENDANTS}

At least one and perhaps several periods of intense folding, reverse faulting, cataclasis, and low-grade regional metamorphism along N. $20^{\circ}-40^{\circ} \mathrm{W}$. trends can be identified in many roof pendants containing Mesozoic metavolcanic or older rocks (fig. 1, table 1). These structures are usually superposed on northtrending structures in areas containing lower Paleozoic metasedimentary rocks. It is tempting to say that all structures with $\mathrm{N} .20^{\circ}-40^{\circ} \mathrm{W}$. trends in the high-country roof pendants resulted from the Late Jurassic Nevadan orogeny; in other roof pendants, however, these structures could have been formed earlier, during the Mesozoic and perhaps the Triassic regional deformations.

\section{ORIENTATION AND SIYLE OF STRLCTURES}

The Late Jurassic Nevadan orogeny can be identified with certainty only in the Ritter Range, Mineral King, Boyden Cave, and Mount Dana roof pendants. The diagrams of poles to axial planes and schistosities for this deformation (fig. 7, table 7 ) show average orientations of N. $20^{\circ}-40^{\circ} \mathrm{W}$. strikes with vertical dips (figs. $7 \mathrm{~A}$, $7 C, 7 T$ ). Fold axes and lineations for the Mineral King and Boyden Cave roof pendants (figs. $7 \mathrm{D}, 7 \mathrm{U}$ ) plunge shallowly to steeply within the northweststriking axial planes. The diagrams of poles to bedding 
for three roof pendants (figs. $7 B, 7 E, 7 \mathrm{~V}$ ) show rotation of bedding into nearly vertical orientations, parallel to axial planes and schistosities. In the Ritter Range roof pendant, poles to bedding are rotated along a great circle and define an initial period of folding on a $\beta_{1}$ axis that plunges subhorizontally to the northwest (fig. $7 B$ ). In the Boyden Cave roof pendant, poles to bedding (fig. $7 \mathrm{~V}$ ) define two great circles that represent the limbs of Early and Middle Jurassic folds and that also define two $\beta$-axes ( $\beta_{1}$ and $\beta_{2}$, fig. $7 \mathrm{~V}$ ) plunging moderately north and south in the N. $20^{\circ} \mathrm{W}$.-striking axial plane. In the Mount Dana roof pendant, Jurassic metavolcanic rocks contain a prominent $\mathrm{N} .25^{\circ}-30^{\circ}$ W.-striking schistosity and are rotated into N. $20^{\circ}-30^{\circ}$ W.-striking folds (Kistler, 1966a; Russell, 1976).

In the Mount Morrison roof pendant a similar Mesozoic deformation occurs; the diagrams of poles to axial planes and schistosities show N. $20^{\circ}-40^{\circ}$ W.striking axial planes with steep dips (figs. $7 F, 7 H$, $7 \mathrm{~K}$ ). The diagrams of fold axes and lineations (figs. $7 G, 7 I, 7 L$ ) show these structures plunging within the axial planes, but with steeper plunges for older Ordovician and Silurian(?) metasedimentary rocks and subhorizontal plunges for younger rocks. The plunges of fold axes and lineations are steep in the older rocks because this folding occurred on the limbs of older folds owing to the Devonian and Mississippian regional deformation, whereas these plunges are subhorizontal in the younger rocks because the folds formed in undeformed subhorizontal strata. The diagram of poles to bedding for Pennsylvanian and Permian(?) metasedimentary rocks (fig. $7 \mathrm{~J}$ ) shows a distribution of poles along a great circle that defines a $\beta$-axis plunging gently at azimuth $330^{\circ}$, nearly coinciding with the maximum of fold axes and lineations.

A similar style and orientation of structures occur in lower Paleozoic rocks of the Dinkey Creek roof pendant (figs. $7 M, 7 N, 7 O$ ) and in Lower Jurassic(?) metasedimentary rocks of the Strawberry mine roof pendant (figs. $7 P, 7 Q, 7 R$ ). In both places the metasedimentary rocks are folded around N. $20^{\circ}-40^{\circ} \mathrm{W}$.striking axial planes with steep dips; both major-and minor-fold axes plunge moderately northwest or southeast. Structures of the N. $20^{\circ}-40^{\circ} \mathrm{W}$. trend are generally superposed on older north-trending structures in roof pendants containing lower Paleozoic rocks. In the Dinkey Creek roof pendant, poles to axial planes and schistosities of an older deformation are rotated around a $\beta$-axis that plunges gently to the northwest (fig. $2 \mathrm{H}$ ). In the Strawberry mine roof pendant, metamorphosed shallow intrusive rocks of early Cretaceous age also contain N. $20^{\circ}-40^{\circ}$ W.-trending folds, faults, and schistosities (fig. $7 S$ ).

The N. $20^{\circ}-40^{\circ}$ W.-trending structures are associ- ated with regional metamorphism of the greenschist facies in many roof pendants, including: (1) Pennsylvanian and Permian(?) metasedimentary rocks and Mesozoic metavolcanic rocks of the Mount Morrison roof pendant (Russell and Nokleberg, 1977), (2) Upper Triassic metasedimentary rocks of the Mineral King roof pendant (Christensen, 1963), (3) Lower Jurassic metavolcanic rocks of the Ritter Range roof pendant (Huber and Rinehart, 1965), and (4) Jurassic metavolcanic rocks of the Mount Dana roof pendant (Russell, 1976).

\section{TIMING OF DEFORMATION AND REGIONAL CORRELATIONS}

A Middle and Late Jurassic age can be inferred for the deformation of only four high-country roof pendants. Crosscutting of the central part of the Ritter Range roof pendant, containing N. $20^{\circ}-40^{\circ}$ W.trending structures and Early Jurassic marine fossils (Huber and Rinehart, 1965), by Early Cretaceous plutonic rocks (O. T. Tobishch and R. S. Fiske, personal commun., 1975) thereby brackets the deformation as Middle and Late Jurassic. Intrusion of the Mineral King and Boyden Cave roof pendants, containing similarly trending structures as well as Late Triassic and Early Jurassic marine fossils, by Early Cretaceous granitic rocks of the Huntington Lake intrusive epoch (Evernden and Kistler, 1970) thereby brackets the deformation as Jurassic. Crosscutting of Mesozoic metavolcanic rocks (probably Permian through Jurassic) of the Mount Morrison roof pendant by Late Cretaceous granitic rocks of the Cathedral Range intrusive epoch (Evernden and Kistler, 1970) thereby brackets the deformation as Jurassic through Cretaceous. In the Mount Dana roof pendant, metavolcanic rocks constituting the lower part of the Dana sequence have been dated as Jurassic, and those constituting the upper part as Early Cretaceous, by a Rb-Sr isochron ( $R$. W. Kistler, unpub. data, 1977). The lower part of the Dana sequence, which contains both older $20^{\circ}-30^{\circ} \mathrm{W}$.trending and younger $\mathrm{N} .60^{\circ} \mathrm{W}$.-trending structures, is unconformably overlain by the upper part, which contains only younger N. $60^{\circ} \mathrm{W}$.-trending structures (Kistler, 1966a, b; Russell, 1976; R. W. Kistler, unpub. data, 1977). These data restrict the deformation along $\mathrm{N}$. $20^{\circ}-30^{\circ} \mathrm{W}$. trends to the Late Jurassic or earliest Cretaceous. In several roof pendants, superposition of the N. $20^{\circ}-40^{\circ} \mathrm{W}$-trending structures on older Devonian and Mississippian structures (Dinkey Creek and Strawberry mine roof pendants) thereby sets the maximum age of deformation at middle Paleozoic. In the Strawberry mine roof pendant, crosscutting of $\mathrm{N}$. $20^{\circ}-40^{\circ} \mathrm{W}$.-trending structures in Lower Cretaceous metavolcanic rocks by Late Cretaceous granitic rocks of the Cathedral Range intrusive epoch (Evernden and 


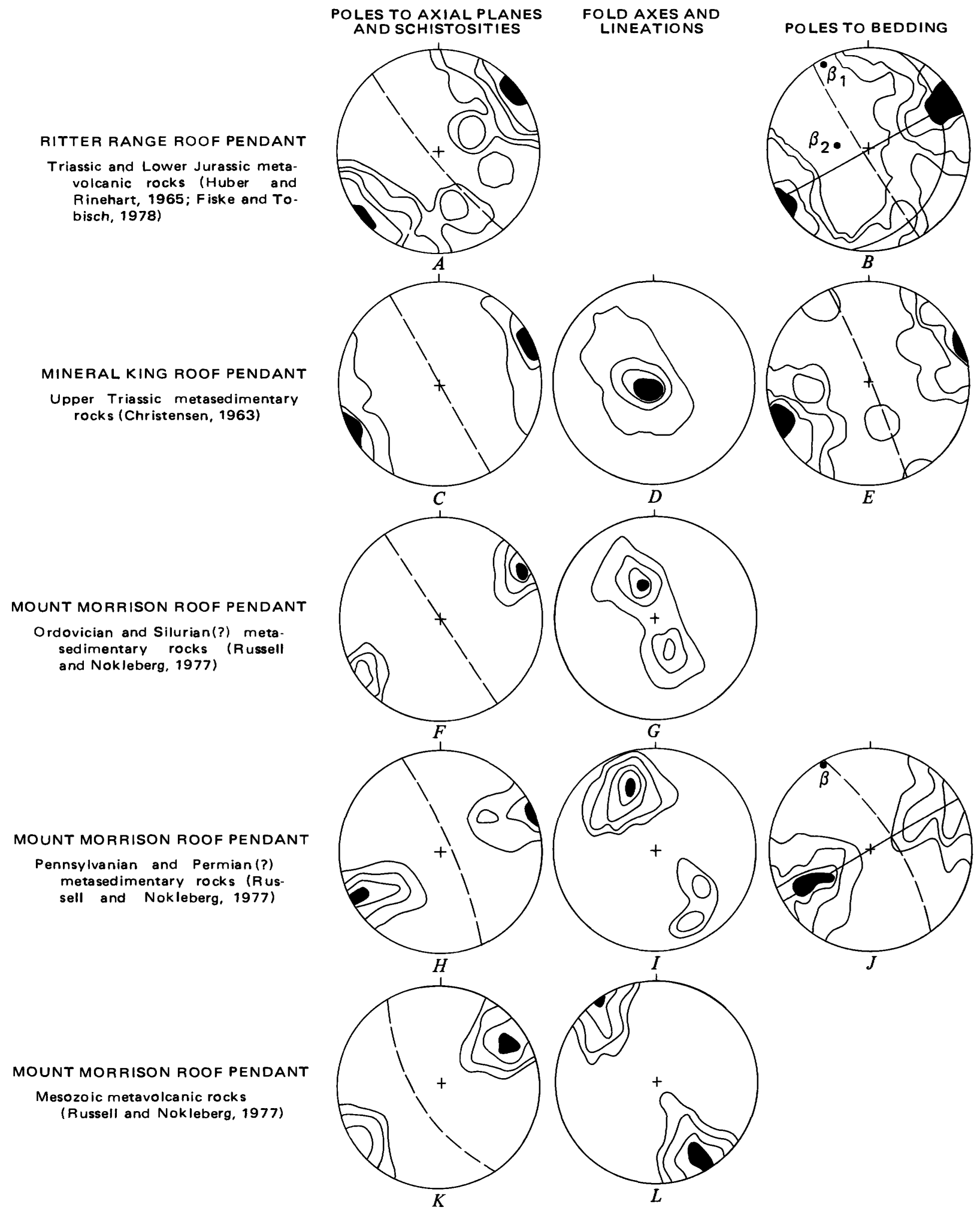

Figure 7.-Structural diagrams for high-country roof pendants deformed probably during Jurassic orogenies along N. $20^{\circ}-40^{\circ}$ W. trends. See figure 2 for explanation. Contour data in table 7.

Kistler, 1970) indicates that in that area the regional deformation along $20^{\circ}-40^{\circ} \mathrm{W}$. trends continued into the Early Cretaceous.
In summary, the recognition of structures with $\mathrm{N}$. $20^{\circ}-40^{\circ} \mathrm{W}$. trends does not associate them with the Late Jurassic Nevadan orogeny because in some areas, 

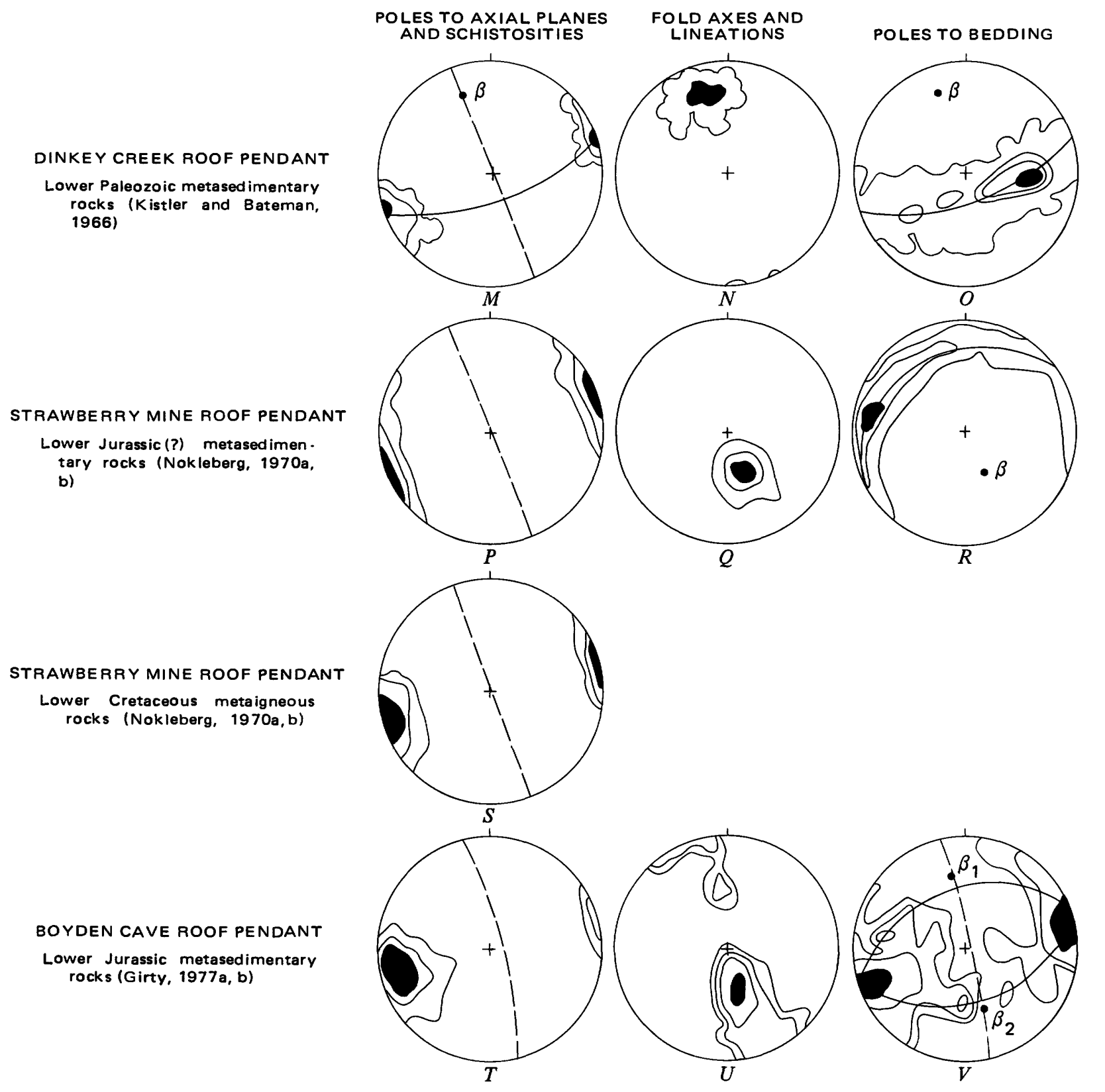

Figure 7.-Continued.

structures with this trend were formed during the Triassic, Late Jurassic, or middle Cretaceous (table 1), and in others only a Mesozoic age of deformation can be determined. In older Paleozoic and lower Mesozoic rocks of the high-country roof pendants, coaxial multiple deformations along N. $20^{\circ}-40^{\circ} \mathrm{W}$. trends are strongly possible.

\section{CRETACEOUS REGIONAL DEFORMATION}

A period of intense folding, cataclasis, and regional metamorphism along N. $50^{\circ}-80^{\circ} \mathrm{W}$. trends can be identified in many high-country roof pendants and in areas of the western metamorphic belt (table 1). These struc- tures occur throughout a wide area, including the Strawberry mine, Pine Creek, Bishop Creek, Ritter Range, Mount Morrison, Mount Dana, and Saddlebag Lake roof pendants, and the lower Kings River area (fig. 1). This generation of structures either is superposed on older generations of structures or occurs in Lower Cretaceous metavolcanic or plutonic rocks that formed after the Late Jurassic Nevadan orogeny.

\section{ORIENTATION AND STYLE OF SIRLC'TL'RES}

The diagrams of poles to axial planes and schistosities for this deformation (fig. 8, table 8) show an average strike of $\mathrm{N} .50^{\circ}-60^{\circ} \mathrm{W}$. with steep to vertical 
TABLE 7.-Data for figure 7

\begin{tabular}{crl}
\hline Diagram & Points & $\begin{array}{c}\text { Contours } \\
\text { (percent per 1 percent area) }\end{array}$ \\
\hline A & & $1.1,2.2,11,20$ \\
B & 92 & $1.2,2.4,7.1,12$ \\
C & 84 & $1,9,17$ \\
D & 255 & $1,9,17$ \\
E & 215 & $3,6,12,18$ \\
F & 34 & $0.8,4.2,13,21$ \\
G & 119 & $1,5.1,10,15.3$ \\
H & 98 & $1,4,8,12$ \\
I & 113 & $1,2,6,10,14$ \\
J & 92 & $0.6,2,4,6$ \\
K & 163 & $0.6,2,8,16$ \\
L & 176 & $1,2,6,12$ \\
M & 87 & $3.2,10,33.3$ \\
N & 29 & $2.1,20$ \\
O & 48 & $0.4,4,5,10$ \\
P & 364 & $1,5,20$ \\
Q & 93 & $1,5,30$ \\
R & 113 & $1,5,15$ \\
S & 46 & $1,5,15$ \\
T & 92 & $1,5,10$ \\
U & 53 & $1,2,15$ \\
V & 98 & $0.4,1,3,7$ \\
\hline
\end{tabular}

dips (figs. $8 A, 8 D, 8 E, 8 G, 8 I, 8 N, 8 O, 8 Q$ ). The diagrams of fold axes and lineations show steep plunges because, in most areas, these structures are superposed on older structures (figs. $8 \mathrm{~B}, 8 \mathrm{~F}, 8 \mathrm{H}, 8 \mathrm{P}$ ). In three roof pendants, double maxima of fold axes and lineations show superposition of these structures on the limbs of folds due to older deformations (figs. $8 F$, $8 \mathrm{H}, 8 \mathrm{~J}, 8 \mathrm{P}$ ). In four roof pendants, diagrams of poles of bedding show a distinct girdle that defines $\beta$-axes plunging moderately to steeply within the N. $50^{\circ}-60^{\circ}$ striking axial planes (figs. $8 \mathrm{C}, 8 \mathrm{~K}, 8 \mathrm{~L}, 8 \mathrm{M}$ ). The match between maxima of poles to bedding and maxima of poles to axial planes and schistosities suggests an isoclinal style of folding.

Two roof pendants show refolding of strata due to this deformation: the northern Ritter Range roof pendant, with rotation of axial planes around a fold axis plunging at azimuth $300^{\circ}$ (fig. $3 \mathrm{D}$ ) and of older fold axes and axial planes into N. $50^{\circ}-60^{\circ} \mathrm{W}$. trends (fig. $3 E$ ); and the central Ritter Range roof pendant, with rotation of bedding around a $\beta$-axis ( $\beta_{2}$, fig. $7 B$ ) plunging at azimuth $290^{\circ}$.

In all areas, intense regional metamorphism and cataclasis are associated with the Cretaceous regional deformation. In most roof pendants, contact metamorphism obscures regional metamorphism and leaves only relict schistosities and lineations; in the lower Kings River area, however, zones of intense cataclasis and recrystallization were formed under conditions of the amphibolite facies in gabbro and granitic rocks (Nokleberg, 1975) dated as Late Jurassic by Saleeby (1974, 1975, 1978).
TIMING OF DEFORMATION AND REGIONAL TECTONICS

In the lower Kings River area, redeformation of the N. $20^{\circ}-40^{\circ}$ W.-trending Nevadan structures in Middle and Late Jurassic gabbro and granitic rocks by $\mathrm{N}$. $50^{\circ}-80^{\circ}$ W.-trending structures (Nokleberg, 1975) thereby defines a post-Jurassic age. Crosscutting of Lower Cretaceous metavolcanic rocks of the Strawberry mine and Merced Peak roof pendants (Nokleberg, 1970a, b; Peck and others, 1977), which contain N. $50^{\circ}-80^{\circ}$ W.-trending structures, by Late Cretaceous (80 m.y. old) granitic rocks of the Cathedral Range intrusive epoch (Evernden and Kistler, 1970) thereby brackets the deformation as middle Cretaceous. In the Mount Dana roof pendant a maximum age of Early Cretaceous is defined for the deformation along $\mathrm{N}$. $50^{\circ}-80^{\circ} \mathrm{W}$. trends (table 1 ). In this area the younger upper part of the Dana sequence has a $\mathrm{Rb}$-Sr isochron age of 100 m.y. (R. W. Kistler, unpub. data, 1977) and contains open major folds striking N. $60^{\circ} \mathrm{W}$. and nea' vertical axial planes (fig. $8 \mathrm{~L}$ ) (Kistler, 1966a, b; Rı.ssell, 1976).

The deformation along N. $50^{\circ}-80^{\circ} \mathrm{W}$. trends alsu occurred in metavolcanic rocks of the northern Ritter Range roof pendant, where it is visible in two small plutons: the granodiorite of Billy Lake, and the quartz diorite of Waugh Lake, which intruded the volcanic pile of the pendant (Kistler, 1960, 1966b). A Rb-Sr whole-rock age of $99 \pm 7$ m.y. on the plutons (R. W. Kistler, unpub. data, 1977) places an older limit of Early Cretaceous on this deformation. Undeformed Late Cretaceous (84 m.y. old) plutons crosscutting these structures in the metavolcanic rocks place a younger limit of middle Late Cretaceous on this deformation.

\section{CONTINUING PROBLEMS}

\section{EPISODIC OR CONTINUOUS DEFORMATION?}

Do the multiple deformations, particularly along $\mathrm{N}$. $20^{\circ}-40^{\circ} \mathrm{W}$. trends during the Mesozoic, represent episodic or continuous responses to compressional subduction along the continental margin? A solution will emerge only as more investigations are completed. The methods of timing multiple deformations in metamorphic terranes involve bracketing relations from such data as the ages of younger less deformed bedrock that overlies or crosscuts older more highly deformed bedrock. Thus, this method indicates only episodes of deformation; continuous deformational patterns will be revealed as enough episodes are defined to fill in all gaps. The solution to this problem is critical to an ultimate understanding of the formation of composite batholiths. 


\section{ROLE OF GRANITIC INTRUSIONS}

Five periods of granitic intrusion are defined for Mesozoic time; granitic rocks of each period form a narrow belt along different trends in California, Oregon, and Nevada (Evernden and Kistler, 1970). Episodic regional deformation and volcanism are associated with these granitic intrusions (Kistler and others, 1971), and so the presence of granitic rocks has several effects on the multiple deformations (Brook and others, 1974; Russell and Nokleberg, 1977). One effect is the shielding of roof pendants, where bordered by major granitic intrusions, from later deformations. For example, the Log Cabin mine and Bishop Creek roof pendants contain structures due to the Devonian and Mississippian regional deformation but not to later deformations because of the presence of Late Triassic $(210 \mathrm{~m} . \mathrm{y}$. old) granitic rocks of the Lee Vining intrusive epoch; similar shieldings of wallrocks from later deformations are listed in table 1. A second effect is the minimal deformation of wallrocks during the emplacement of granitic magmas, except for a few examples of forceful emplacement reported by Bateman (1965). One conclusion, based on the correlation of superposed deformations across the central Sierra Nevada, is that the intrusion of granite was predominantly passive (Kistler, 1966a; Brook and others, 1974; Russell and Nokleberg, 1977). A third effect is that, in areas of the western metamorphic belt, regionally deformed plutons can be recognized and delineated (Nokleberg, 1975).

\section{CONJUGATE FOLDS}

In a recent study of conjugate folds and crenulations in the central Sierra Nevada, Tobisch and Fiske (1976) stated that: (1) the crenulation or folding of slaty cleavage or schistosity in one area may not be contemporaneous with a geometrically comparable structure in another area, (2) crenulations in one area may even predate slaty cleavage or schistosity in another area, and (3) the fold chronology that defines multiple folding in the Sierra Nevada needs reexamination. We agree that conjugate folding of schistosities has occurred but, in our view, only on a limited scale; we disagree with the concept that refolding of a slaty cleavage in most areas is related to the formation of conjugate folds that represent different stages of the Nevadan orogeny.

We assert that the refolding of slaty cleavage or axial-plane schistosities and associated folds is principally related to superposed regional deformations, for several reasons. First, examples of conjugate folds are quite rare. Tobisch and Fiske found only a few such folds; their figure 5a shows mainly northwest- and east-trending, but no west- or north-trending, folds, as the figure caption states; their figure $5 \mathrm{~b}$ shows only random orientations of folds with no clearly discernible maxima of conjugate pairs. Second, many of the westtrending halves of conjugate folds described by Tobisch and Fiske may represent superposed folds due to a later deformation; their figure $3 \mathrm{a}$ shows west-trending conjugate folds crossing a N. $20^{\circ}-40^{\circ}$ W.-trending schistosity associated with the Nevadan orogeny in the central part of the Ritter Range roof pendant. The west-trending folds are actually $\mathrm{N} .50^{\circ}-80^{\circ} \mathrm{W}$.trending folds that may have formed during the early Late Cretaceous regional deformation. Third, Tobisch and Fiske state in a footnote (1976, p. 1419) that "**** some zones of slaty cleavage in the southwest Ritter Range pendant may postdate the Nevadan deformation"; their claim is supported by radiometric age dating of rocks in the Ritter Range roof pendant (R. W. Kistler, T. W. Stern, and Mitsunobu Tatsumoto, personal communs., 1973-75). These reasons clearly show that superposed schistosities and, presumably, superposed folds were formed during separate deformations in one of the type areas of Tobisch and Fiske for conjugate folds.

In contrast to the notion that the conjugate refolding of schistosities represents a continuation of the Nevadan orogeny, our study shows many distinct periods of regional deformation. Many statements by Tobisch and Fiske support our study: (1) three periods of deformation occur in Paleozoic metasedimentary rocks-and only the younger two occur in metavolcanic rocks of late Paleozoic and Mesozoic age; (2) an axial-plane cleavage or schistosity occurs in Paleozoic rocks that predates the Nevadan cleavage; and (3) some zones of slaty cleavage or schistosity in the Ritter Range roof pendant may postdate the Nevadan orogeny.

\section{CONCLUSIONS}

Analysis of structural and stratigraphic data indicates that several regional deformations occurred in the central Sierra Nevada during the Paleozoic and Mesozoic. Each regional deformation is characterized by a combination of folds, cataclasis, regional metamorphism, and faulting. The oldest recognized regional deformation occurred along northward trends during the Devonian to Mississippian and occurs in roof pendants containing lower Paleozoic rocks along the center and crest of the range. An angular unconformity formed during the Devonian to Mississippian in the Mount Morrison roof pendant that separates older thrice-deformed rocks from younger twicedeformed rocks. A period of uplift, erosion, and commencement of Andean-type volcanism occurred in the Permian to Triassic and is now represented by an in- 


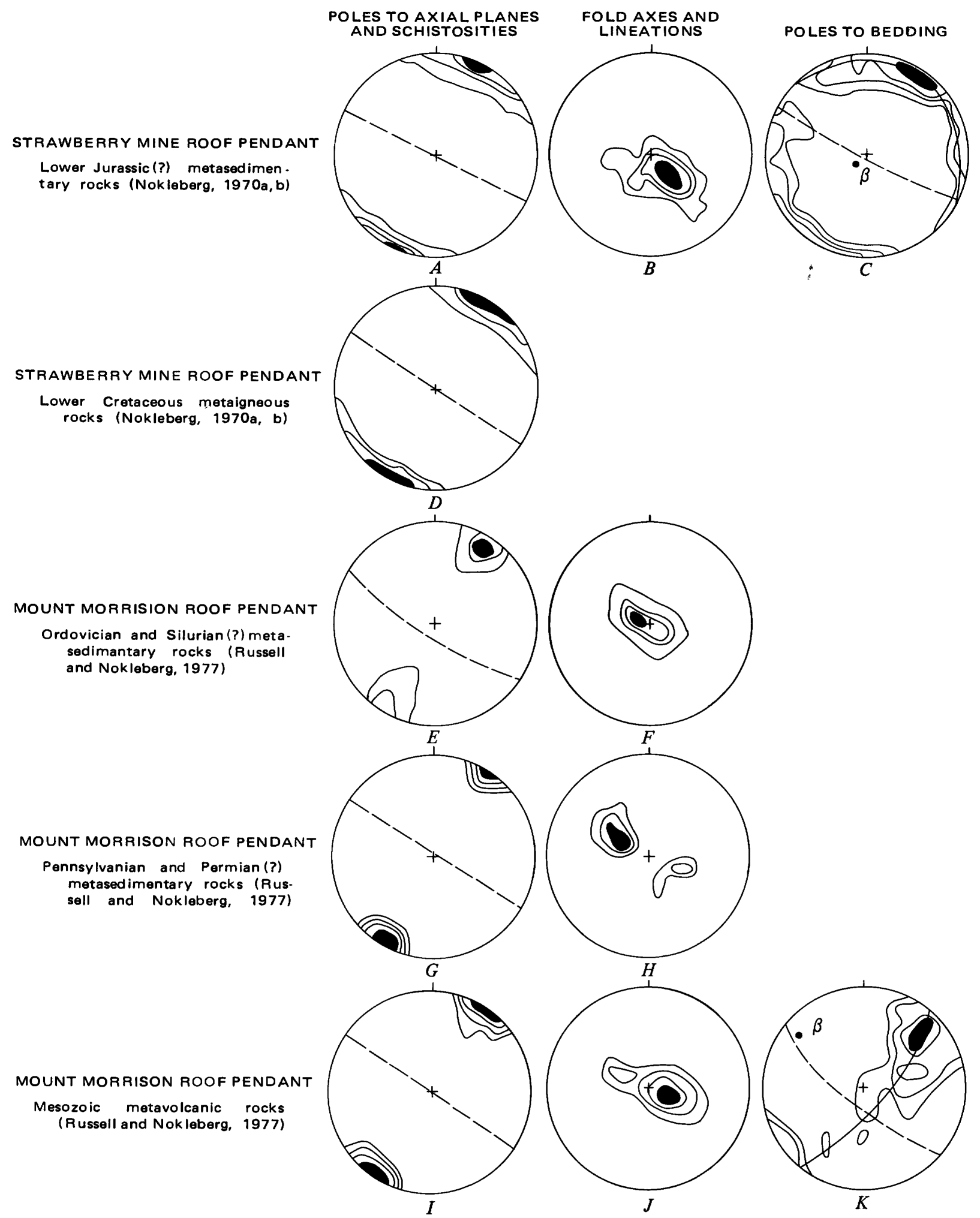

FIGURE 8.-Structural diagrams for high-country roof pendants and areas of the western metamorphic belt deformed during the Cretaceous along N. $50^{\circ}-80^{\circ} \mathrm{W}$. trends. See figure 2 for explanation. Contour data in table 8.

gular unconformity in several roof pendants along the crest of the range. During the Triassic, regional deformations occurred along $\mathrm{N} .20^{\circ}-30^{\circ} \mathrm{W}$. trends in several high-country roof pendants and in the Calaveras Formation of the western metamorphic belt. A later Early Middle Jurassic deformation occurred along N. $30^{\circ}-60^{\circ}$ 
POLES TO AXIAL PLANES AND SCHISTOSITIES

MOUNT DANA ROOF PENDANT

Lower Cretaceous metavolcanic rocks (Kistler, 1966a, b; Russell, 1976)

DINKEY CREEK ROOF PENDANT

Lower Paleozoic metasedimen

tary rocks ( $K$ istler and Bate-

man, 1966)

FOLD AXES AND
LINEATIONS
POLES TO BEDDING

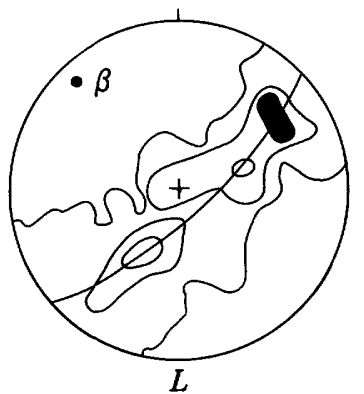

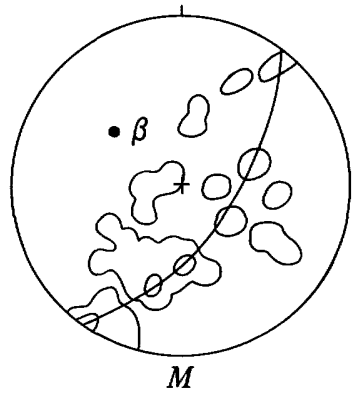

\section{SADDLEBAG LAKE ROOF PENDANT \\ Permian and Triassic metavolcanic rocks (Brook, 1972, 1974, 1977)}
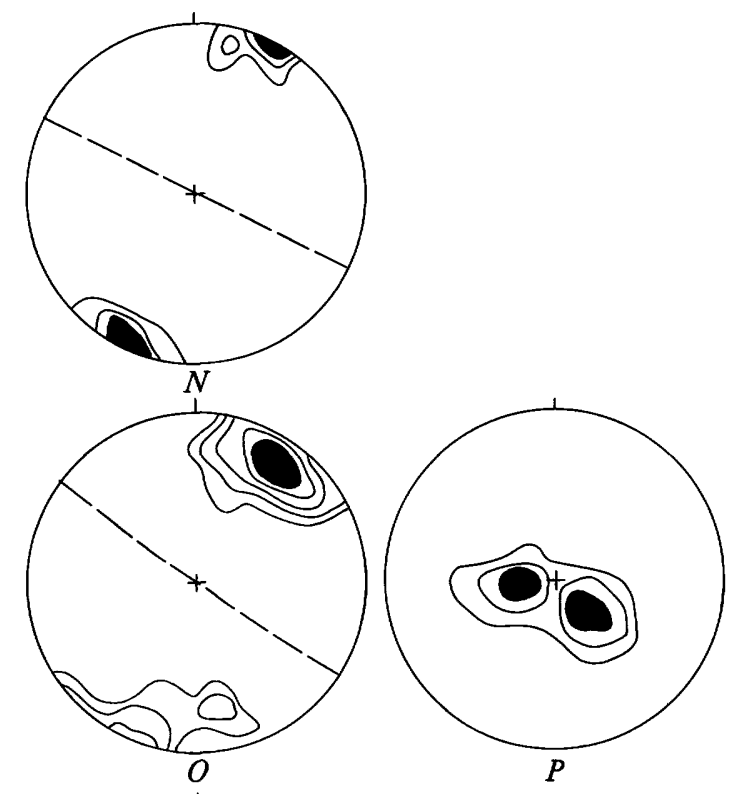

\section{Metasedimentary rocks Calaveras (?) \\ Formation, upper Paleozoic (?) (Nokleberg, 1975) \\ LOWER KINGS RIVER ROOF PENDANT}

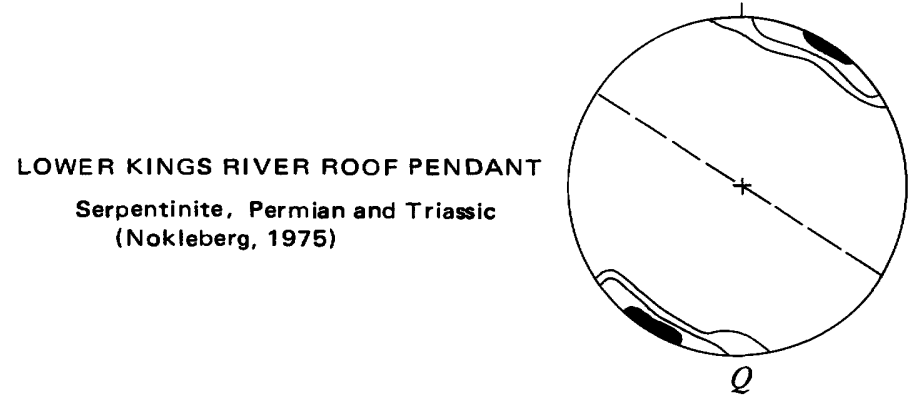

FIGURE 8.-Continued.

E. trends in the western metamorphic belt and Boyden Cave roof pendant. In the high-country roof pendants, the Triassic structures are crosscut by Late Triassic granitic rocks of the Lee Vining intrusive epoch. The Late Jurassic Nevadan orogeny consisted of both right-lateral strike slip and underthrusting along $\mathrm{N}$. 
TABLE 8.-Data for figure 8

\begin{tabular}{crl}
\hline Diagram & Points & \multicolumn{1}{c}{$\begin{array}{c}\text { Contours } \\
\text { (percent per 1 percent area) }\end{array}$} \\
\hline A & 103 & $1,5,10,20$ \\
B & 42 & $1,5,10,20$ \\
C & 136 & $1,2,4,6$ \\
D & 73 & $1,5,10$ \\
E & 85 & $1.1,12,25$ \\
F & 50 & $0.2,10,20,30$ \\
G & 17 & $5,10,15,20,30$ \\
H & 16 & $5,10,20$ \\
I & 82 & $1,4,12,28$ \\
J & 54 & $2,4,10,18$ \\
K & 66 & $0.6,2,4,8$ \\
L & 175 & $0.5,3,5$ \\
M & 45 & $2.2,6.6$ \\
N & 25 & $8,24,32$ \\
O & 59 & $1,2,4,8,12$ \\
P & 56 & $1,4,12$ \\
Q & 18 & $1,10,20$ \\
\hline
\end{tabular}

$20^{\circ}-40^{\circ} \mathrm{W}$. trends. This orogeny ended with the emplacement of Late Jurassic granitic rocks of the Yosemite intrusive epoch. Some early intrusions of this epoch may have been emplaced during the waning stages of the orogeny. One or two high-country roof pendants were deformed along $\mathrm{N} .20^{\circ}-40^{\circ} \mathrm{W}$. trends during the Nevadan orogeny, but many other roof pendants could have been deformed along the same trends somewhat earlier or later. The last major regional deformation occurred during the early Late Cretaceous, when most roof pendants and parts of the western metamorphic belt were deformed along $\mathrm{N}$. $50^{\circ}-80^{\circ} \mathrm{W}$. trends. This deformation was followed by the Late Cretaceous Cathedral Range intrusive epoch.

In the roof pendants of the eastern Sierra Nevada, multiply folded thin formations are found instead of homoclinal thick formations, as proposed earlier. Paleozoic rocks of the western metamorphic belt are folded around axes that plunge steeply east across the batholith, whereas Mesozoic rocks of the western metamorphic belt are folded around axes plunging moderately to steeply southeast instead of subhorizontal and parallel to the batholith. Older thrice-deformed roof pendants of early Paleozoic age occur in the center and along the east side of the batholith. The highcountry roof pendants show considerable differences in stratigraphy, structural trends, and number of deformations in comparison to areas of the western metamorphic belt.

The available evidence suggests episodic regional deformations. Some roof pendants containing lower Paleozoic and lower Mesozoic rocks may have been multiply deformed along coaxial N. $20^{\circ}-40^{\circ} \mathrm{W}$. trends. The role of granitic intrusions has been to shield encir- cled roof pendants from subsequent deformation, although regionally deformed plutons are recognized in the western metamorphic belt. The correlation of superposed deformations across the range suggests that granitic intrusions were mainly passive in the central Sierra Nevada.

\section{ACKNOWLEDGMENTS}

We are grateful for many discussions of this topic with C. A. Brook, S. J. Russell, G. H. Girty, and S. F. Cebull. We thank R. A. Loney and C. A. Brook for their reviews of the manuscript. We are indebted to the excellent older studies by many geologists of the central Sierra Nevada; if we have been able to see further into the geology of the region, it is only because we have stood on their shoulders for a better view.

\section{REFERENCES CITED}

Baird, A. K., 1962, Superposed deformations in the central Sierra Nevada foothills east of the Mother Lode: University of California Publications in Geological Sciences, v. 42 , no. 1, p. 1-70.

Bateman, P. C., 1965, Geology and tungsten mineralization of the Bishop district, California, with a section on Gravity study of Owens Valley, by L. C. Pakiser and M. F. Kane, and $a$ section on Seismic profile, by L. C. Pakiser: U.S. Geological Survey Professional Paper 470, 280 p.

Bateman, P. C., and Clark, L. D., 1974, Stratigraphic and structural setting of the Sierra Nevada batholith, California: Pacific Geology, v. 8, p. 79-89.

Bateman, P. C., Clark, L. D., Huber, N. K., Moore, J. G., and Rinehart, C. D., 1963, The Sierra Nevada batholith-a synthesis of recent work across the central part: U.S. Geological Survey Professional Paper 414-D, p. D1-D46.

Berkland, J. D., Raymond, L. A., Kramer, J. C., Moores, E. M., and O'Day, M. O., 1972, What is Franciscan?: American Association of Petroleum Geologists Bulletin, v. 56, no. 12, p. 2295-2302.

Best, M. G., 1963, Petrology and structural analysis of metamorphic rocks in the southwestern Sierra Nevada foothills, California: University of California Publications in Geological Sciences, v. 42 , no. 3, p. 111- 158 .

Brook, C. A., 1972, Stratigraphy and superposed deformations of parts of the Saddlebag Lake roof pendant, Sierra Nevada, California: Fresno, California State University M.S. thesis, 47 p. 1974, Nature and significance of superposed folds in the Saddlebag Lake roof pendant, Sierra Nevada, California [abs.]: Geological Society of America Abstracts with Programs, v. 6, no. 3, p. 147-148.

- 1977, Stratigraphy and structure of the Saddlebag Lake roof pendant, Sierra Nevada, California: Geological Society of America Bulletin, v. 88, no. 3, p. 321-334.

Brook, C. A., Nokleberg, W. J., and Kistler, R. W., 1974, Nature of the angular unconformity between the Paleozoic metasedimentary rocks and the Mesozoic metavolcanic rocks in the eastern Sierra Nevada, California: Geological Society of America Bulletin, v. 85 , no. 4 , p. $571-576$.

Burchfiel, B. C., and Davis, G. A., 1972, Structural framework and evolution of the southern part of the Cordilleran orogen, western United States: American Journal of Science, v. 272, no. 2, p. 97-118. 
Christensen, M. N., 1963, Structure of metamorphic rocks at Mineral King, California: University of California Publications in Geological Sciences, v. 42, no. 4, p. 159-198.

Clark, L. D., 1954, Geology and mineral deposits of Calaveritas quadrangle, Calaveras County, California: California Department of Natural Resources, Division of Mines Special Report 40, $23 \mathrm{p}$.

1960, Foothills fault system, western Sierra Nevada, California: Bulletin of the Geological Society of America, v. 71, no. 4, p. 483-496.

-1964 , Stratigraphy and structure of part of the western Sierra Nevada metamorphic belt, California: U.S. Geological Survey Professional Paper 410, 70 p.

1970, Geology of the San Andreas 15-minute quadrangle, Calaveras County, California: California Division of Mines and Geology Bulletin 195, 23 p.

Davis, G. A., Monger, J. W. H., and Burchfiel, B. C., 1978, Mesozoic construction of the Cordilleran "collage," central British Columbia to central California, in Howell, D. G., and McDougall, K. A., eds., Mesozoic paleogeography of the western United States: Pacific Coast Paleogeography Symposium, 2d, Sacramento, Calif., 1978: Los Angeles, Society of Economic Paleontologists and Mineralogists, Pacific Section, p. 1-32.

Duffield, W. A., and Sharp, R. V., 1975, Geology of the Sierra Foothills Melange and adjacent areas, Amador County, California: U.S. Geological Survey Professional Paper 827, 30 p.

Eric, J. H., Stromquist, A. A., and Swinney, C. M., 1955, Geology and mineral deposits of the Angels Camp and Sonora quadrangles, Calaveras and Tuolumne Counties, California: California Division of Mines and Geology Special Report 41, 55 p.

Evernden, J. F., and Kistler, R. W., 1970, Chronology of emplacement of Mesozoic batholithic complexes in California and western Nevada: U.S. Geological Survey Professional Paper 623, 42 p.

Fiske, R. S., and Tobisch, O. T., 1978, Paleographic significance of volcanic rocks of the Ritter Range pendant, central Sierra Nevada, California, in Howell, D. G., and McDougall, K. A., eds., Mesozoic paleogeography of the western United States: Pacific Coast Paleogeography Symposium, 2d, Sacramento, Calif., 1978: Los Angeles, Society of Economic Paleontologists and Mineralogists, Pacific Section, p. 209-222.

Girty, G. H., 1977a, Cataclastic rocks in the Boyden Cave roof pendant, central Sierra Nevada, California [abs.]: Geological Society of America Abstracts with Programs, v. 9, no. 4, p. 423.

$-1977 \mathrm{~b}$, Multiple regional deformation and metamorphism of the Boyden Cave roof pendant, central Sierra Nevada, California: Fresno, California State University M.S. thesis, 82 p.

Hamilton, Warren, 1969, Mesozoic California and the underflow of Pacific mantle: Geological Society of America Bulletin, v. 80, no. 12, p. 2409-2429.

1978, Mesozoic tectonics of the western United States, in Howell, D. G., and McDougall, K. A., eds., Mesozoic paleogeography of the western United States: Pacific Coast Paleogeography Symposium, 2d, Sacramento, Calif., 1978: Los Angeles, Society of Economic Paleontologists and Mineralogists, Pacific Section, p. 33-70.

Huber, N. K., and Rinehart, C. D., 1965, Geologic map of the Devils Postpile quadrangle, Sierra Nevada, California: U.S. Geological Survey Geologic Quadrangle Map GQ-437, scale $1: 62,500$.

Jones, D. L., and Moore, J. G., 1973, Lower Jurassic ammonite from the south-central Sierra Nevada, California: Journal of Research of the U.S. Geological Survey, v. 1, no. 4, p. 453-458.

Kerrick, D. M., 1960, Contact metamorphism in some areas of the Sierra Nevada, California: Bulletin of the Geological Society of America, v. 81 , no. 10 , p. $2913-2938$.
Kistler, R. W., 1960, The geology of the Mono Craters quadrangle, California: Berkeley, University of California Ph.D. thesis, $130 \mathrm{p}$.

-1966a, Structure and metamorphism in the Mono Craters quadrangle, Sierra Nevada, California: U.S. Geological Survey Bulletin 1221-E, p. E1-E53.

$-1966 \mathrm{~b}$, Geologic map of the Mono Craters quadrangle, Mono and Tuolumne Counties, California: U.S. Geological Survey Geologic Quadrangle Map GQ-462, scale $1: 62,500$.

Kistler, R. W., and Bateman, P. C, 1966, Stratigraphy and structure of the Dinkey Creek roof pendant in the central Sierra Nevada, California: U.S. Geological Survey Professional Paper 524-B, p. B1-B14.

Kistler, R. W., Evernden, J. F., and Shaw, H. R., 1971, Sierra Nevada plutonic cycle: Part 1 . Origin of composite granitic batholiths: Geological Society of America Bulletin, v. 82, no. 4, p. 853-868.

Kistler, R. W., and Peterman, Z. E., 1978, The reconstruction of crustal blocks of California on the basis of initial strontium isotopic compositions of Mesozoic granitic rocks: U.S. Geological Survey Professional Paper 1071, 17 p.

Mannion, L. E., 1960, Geology of the La Grange quadrangle, California: Stanford, Calif., Stanford University Ph.D. thesis, 173 p.

Moores, E. M., 1970, Ultramafics and orogeny, with models of the U.S. cordillera and the tethys: Nature, v. 228 , no. 4274 , p. $837-$ 842.

Morgan, B. A., and Rankin, D. W., 1972, Major structural break between Paleozoic and Mesozoic rocks in the eastern Sierra Nevada, California: Geological Society of America Bulletin, v. 83, no. 12 , p. $3739-3744$.

Nokleberg, W. J., 1970a, Multiple folding in the Strawberry Mine roof pendant, central Sierra Nevada, California [abs.]: Geological Society of America Abstracts with Programs, v. 2, no. 2, p. 125- 126.

1970b, Geology of the Strawberry Mine roof pendant, central Sierra Nevada, California: Santa Barbara, University of California Ph.D. thesis, 156 p.

-1975 , Structural analysis of a collision between an oceanic plate and a continental plate preserved along the lower Kings River in the Sierra Nevada [abs.]: Geological Society of America Abstracts with Programs, v. 7, no. 3, p. 357-358.

Parker, R. B., 1961, Petrology and structural geometry of pregranitic rocks in the Sierra Nevada, Alpine County, California: Geological Society of America Bulletin, v. 72, no. 12, p. 1789 1806.

Peck, D. L., Stern, T. W., and Kistler, R. W., 1977, Penecontemporaneous volcanism and intrusion in the Sierra Nevada batholith, California [abs.]: International Associations of Seismology and Physics and Volcanology and Chemistry of the Earth's Interior, Joint General Assemblies, Durham, N.C., 1977, abstracts volume.

Rinehart, C. D., and Ross, D. C., 1964, Geology and mineral deposits of the Mount Morrison quadrangle, Sierra Nevada, California, with a section on A gravity study of Long Valley, by L. C. Pakiser: U.S. Geological Survey Professional Paper 385, 106 p.

Russell, L. R., and Cebull, S. F., 1977, Structural-metamorphic chronology in a roof pendant near Oakhurst, California: Implications for the tectonics of the western Sierra Nevada: Geological Society of America Bulletin, v. 88, no. 10, 1530-1534.

Russell, S. J., 1976, Geology of the Mount Dana roof pendant, central Sierra Nevada, California: Fresno, California State University M.S. thesis, 86 p.

Russell, S. J., and Nokleberg, W. J., 1974, The relation of superposed deformations in the Mount Morrison roof pendant to the regional tectonics of the Sierra Nevada [abs.]: Geological Society of America Abstracts with Programs, v. 6, no. 3, p. 245. 
1977, Superimposition and timing of deformations in the Mount Morrison roof pendant and in the central Sierra Nevada, California: Geological Society of America Bulletin, v. 88, no. 3, p. 335-345.

Saleeby, J. B., 1974, Preliminary report on the mafic-ultramafic belt of the southwestern Sierra Nevada foothills, California [abs.]: Geological Society of America Abstracts with Programs, v. 6, no. 3, p. 247.

1975, Serpentinite melange belt-southwestern Sierra Nevada foothills, California[abs.]: Geological Society of America Abstracts with Programs, v. 7, no. 3, p. 367-368.

1976 , Zircon $\mathrm{Pb} / \mathrm{U}$ geochronology of the Kings-Kaweah ophiolite belt-southwestern Sierra Nevada foothills, California [abs.]: Geological Society of America Abstracts with Programs, v. 8 , no. 3, p. 405-406.

1978, Kings River ophiolite, southwest Sierra Nevada foothills, California: Geological Society of America Bulletin, v. 89, no. 4, p. 617-636.

Saleeby, J. B., Goodin, S. W., Sharp, W. D., and Busby, C. J., 1978, Early Mesozoic paleotectonic-paleogeographic reconstruction of the southern Sierra Nevada region, in Howell, D. G., and McDougall, K. A., eds., Mesozoic paleogeography of the western United States: Pacific Coast Paleogeography Symposium, 2d, Sacramento, Calif., 1978: Los Angeles, Society of Economic Paleontologists and Mineralogists, Pacific Section, p. 311-336.

Schweickert, R. A., 1978, Triassic and Jurassic paleogeography of the Sierra Nevada and adjacent regions, California and western Nevada, in Howell, D. G., and McDougall, K. A., eds., Mesozoic paleogeography of the western United States: Pacific Coast Paleogeography Symposium, 2d, Sacramento, Calif., 1978: Los Angeles, Society of Economic Paleontologists and Mineralogists, Pacific Section, p. 361-384.

Schweickert, R. A., and Cowan, D. S., 1975, Early Mesozoic tectonic evolution of the western Sierra Nevada, California: Geological Society of America Bulletin, v. 86, no. 10, p. 1329-1336.

Schweickert, R. A., Saleeby, J. B., Tobisch, O. T., and Wright, W. H.,
III, 1977, Paleotectonic and paleogeographic significance of the Calaveras Complex, western Sierra Nevada, California, in Stewart, J. H., Stevens, C. H., and Fritsche, A. E., eds., Paleozoic paleogeography of the western United States: Pacific Coast Paleogeography Symposium, 1st, Bakersfield, Calif., 1977: Los Angeles, Society of Economic Paleontologists and Mineralogists, Pacific Section, p. 381-394.

Silberling, N. J., and Roberts, R. J., 1962, Pre-Tertiary stratigraphy and structure of northwestern Nevada: Geological Society of America Special Paper 72, 58 p.

Silver, L. T., and Anderson, T. H., 1974, Possible left-lateral early to middle Mesozoic disruption of the southwestern North America craton margin [abs.]: Geological Society of America Abstracts with Programs, v. 6, no. 7, p. 955-956.

Speed, R. C., 1971, Permo-Triassic continental margin tectonics in western Nevada [abs.]: Geological Society of America Abstracts with Programs, v. 3, no. 2, p. 199.

Speed, R. C., and Kistler, R. W., 1977, Correlations between preTertiary rocks of the Great Basin and the Sierra Nevada [abs.]: Geological Society of America Abstracts with Programs, v. 9, no. 4, p. 505-506.

Taliaferro, N. L., and Solari, A. J., 1948, Geology of the Copperopolis quadrangle, California: California Division of Mines and Geology Bulletin 415, $64 \mathrm{p}$.

Tobisch, O. T., and Fiske, R. S., 1976, Significance of conjugate folds and crenulations in the central Sierra Nevada, California: Geological Society of America Bulletin, v. 87, no. 10, p. 14111420 .

Weiss, L. E., 1959, Geometry of superposed folding: Bulletin of the Geological Society of America, v. 70, no. 1, p. 91-106.

Wetzel, Nicholas, and Nokleberg, W. J., 1976, Plate tectonic and structural relations for the origin and deformation of the western metamorphic belt along the margin of the central Sierra Nevada batholith[abs.]: Geological Society of America Abstracts with Programs, v. 8, no. 3, p. 420. 